\title{
Air Pollution and Stock Returns: Evidence from a Natural Experiment
}

\author{
Gabriele M. Lepori ${ }^{\mathrm{a}, \mathrm{b}}$ \\ (ACCEPTED VERSION of a paper published in the Journal of Empirical Finance)
}

\begin{abstract}
Previous studies have documented the existence of a relationship between air pollution and people's moods and between people's moods and stock returns. To investigate if the link between local air pollution and domestic equity returns is mediated by the trading floor community, we use the transition of Italy's main stock exchange from a trading floor technology to an electronic and delocalized trading system as a natural experiment. In addition, we take advantage of differences in trading technology across a sample of major international stock exchanges. In both instances, we document the existence of an air pollution effect only when trading is conducted on the floor, which provides evidence in support of the view that the air pollution effect is at least partly mediated by the behavior of the trading floor community.
\end{abstract}

JEL classification: G02, G11, G12, G14

Keywords: Air pollution; negative mood; stock returns; trading technology.

\footnotetext{
a Department of Finance, Copenhagen Business School, Solbjerg Plads 3, A5.36, 2000 Frederiksberg, Denmark.

${ }^{\mathrm{b}}$ Current affiliation: Keele Management School, Keele University, Staffordshire, ST5 5BG, United Kingdom. Tel. +44 (0)1782 733889. Email: g.lepori@keele.ac.uk. I would like to thank the Editor, an Associate Editor, and seminar participants at Copenhagen Business School, Rouen School of Management, St. John's University's Financial Services Symposium, the XVII International Rome Tor Vergata conference on Banking and Finance, the MFA annual meeting in Chicago, the EFA annual meeting in Washington, and the $12^{\text {th }}$ Conference of the Swiss Society for Financial Market Research for helpful comments and suggestions. All remaining errors are mine.
} 
There's so much pollution in the air now that if it weren't for our lungs there'd be no place to put it all - Robert Orben

\section{Introduction}

Marketing researchers have been investigating for decades whether and how the store environment can be manipulated so as to influence consumer purchases (Turley and Milliman, 2000). For example, background music has long been in use in retail stores and offices, allegedly to elicit certain desired behaviors or attitudes among shoppers or employees (Milliman, 1982; Bruner, 1990). This kind of analysis finds support in the psychological literature, which has shown that the emotional state experienced at the time of making a choice can bias the decision-making process. ${ }^{1}$ In the field of finance, there is a growing body of evidence that some local environmental factors influence trading decisions and equity returns. For example, Saunders (1993) and Hirshleifer and Shumway (2003) document the existence of a negative relationship between local cloud cover (i.e. measured in the city that hosts a given stock exchange) and domestic stock returns; analogously, Levy and Yagil (2011) find that air pollution levels near the NYSE and AMEX are negatively related to U.S. stock returns. However, a question that is still unresolved is who are the agents that are responsible for such effects. In the present paper, we replicate and extend the work of Levy and Yagil and other behavioral finance scholars by investigating both whether there exists a relationship between air pollution, trader mood, and equity returns and whether such a relationship is mediated by the impact that local air pollution exerts on the behavior of the trading floor community. ${ }^{2} \mathrm{We}$ initially test our air pollution hypothesis using data from the Italian stock market and exploiting a natural experiment generated by the transition of the Milan Stock Exchange (MSE) from a trading floor technology to a floorless one in the middle of the 1990's. Using a binary response model and controlling for well-

\footnotetext{
${ }^{1}$ See, for example, Schwartz and Clore (1983), Johnson and Tversky (1983), Schwartz (1990), MacLeod and Campbell (1992), Mann (1992), and Isen and Labroo (2003).

2 Among the authors suggesting that floor traders not only execute orders but can also affect stock prices, see for example Saunders (1993), Sofianos and Werner (2000), and Limpaphayom et al. (2007). The role played by the floor community will be discussed in depth in section 2 . 
known calendar anomalies and behavioral factors, we estimate that, during the centralized market era, a 10 $\mu \mathrm{g} / \mathrm{m}^{3}$ (one standard deviation) increase in the concentrations of particulate matter on day $t-1$ reduces the probability that stock returns will be positive on day $t$ by approximately $1.5 \%(7 \%)$. In terms of magnitude, we estimate that a $10 \mu \mathrm{g} / \mathrm{m}^{3}$ (one standard deviation) increase in air pollution on day $t-1$ is followed by a drop in stock returns of about 3 (14) basis points on day $t$. These results are both statistically and economically significant and stay qualitatively unchanged when we employ an IV estimation to control for potential sources of endogeneity. Though we find some evidence that the magnitude of the pollution effect decreased after the transition to a floorless technology, our data do not irrefutably show that such an effect disappeared entirely and, as such, based on the natural experiment in question it is not possible to conclude that the relationship between local air pollution and equity returns is entirely mediated by the influence that the former exerts on the trading floor community.

To shed more light on the issue, we then replicate our analysis using data for the leading stock exchanges of the United States, Canada, Ireland, Spain, UK, France, Germany, China, and Australia. We do so in order to exploit the variation in trading technology across stock exchanges, as some of the exchanges in question featured an active trading floor community during the sample period while some others employed a floorless technology. In the case of the exchanges that employ a trading floor technology, we find evidence of a negative link between local air pollution and the probability that the corresponding market indices will deliver a positive return. On the other hand, no significant relationship is detected when floorless exchanges are considered. The results we present are remarkable on two grounds. First, they corroborate the findings on the role that psychological factors play in asset pricing. Second, they provide evidence that the trading floor community plays a mediating role between local air pollution (and possibly other local environmental variables) and aggregate asset price fluctuations.

The rest of the paper is organized as follows. Section 1 discusses the mechanisms through which psychological factors are conjectured to sway investment decisions and comments on the empirical evidence produced so far. Section 2 describes how the trading floor community may exercise an influence 
on asset prices. Section 3 gives on overview of the air pollution phenomenon and examines the effects it has been found to exert on the human body and psyche. Section 4 discusses the hypotheses under investigation, and section 5 illustrates the dataset. The empirical analysis is conducted in section 6 , which also contains a battery of robustness checks and addresses some potential sources of endogeneity. Section 7 provides some international evidence, and section 8 discusses the overall results.

\section{Affective State and Decision-Making}

The link between affect and choice has long interested psychologists. Byrne and Clore (1970) maintain that "affect elicited by a stimulus conditions behavior and attitudes toward other stimuli merely associated with it". In other words, the emotional state experienced at the time a decision is being made is likely to condition the decision itself (Isen et al., 1978; Frijda, 1988; Forgas, 1995; Loewenstein, 2000), for emotions are believed to regulate thought and inform judgment and cognitive evaluations (Damasio, 1994; Loewenstein et al., 2001). Many emotions are believed to have emerged as useful responses from evolutionary conditioning (Frank, 1988; LeDoux, 1996), and help individuals economize on information processing, as "emotion allows people to transcend the details, prioritize, and focus on the decision to be made" (Ackert et al., 2003). Psychologists posit that the same rules of thumb (or heuristics) that regularly help people make decisions, might occasionally lead them astray. When mood works as a "source of information" to individuals, it might influence their choices even in those circumstances when the source of the mood state does not have anything to do with the decision being made, i.e. a mechanism of "mood misattribution" may be at work (Schwartz and Clore, 1983; Schwartz, 1990). Product choice, purchase intentions, behavior traits, and actual purchases have all been shown to be partly affected by (apparently irrelevant) factors such as in-store music, ambient scent and illumination. ${ }^{3}$ In the field of finance, what has attracted the attention of scholars is the link between mood and trading decisions. The focus has been on

\footnotetext{
${ }^{3}$ See, for example, Milliman (1982), McElrea and Standing (1992), Areni and Kim (1993), Gulas and Bloch (1995), North and Hargreaves (1996; 1997; 1998), and Summers and Hebert (2001). 
trying to identify some environmental variables that act as mood proxies for large groups of investors, the rationale being that changes in the environment may trigger mood changes and, ultimately, have an impact on investment decisions (for example, through the mood misattribution mechanism). One of the earliest contributions in this area can be traced back to Saunders (1993), who, utilizing the level of cloud cover in New York City as a proxy for trader mood, observes that such a factor exhibits a significant relationship with the returns of three global indices of the U.S. stock market. Along similar lines, alternative environmental factors have been used as proxies in an attempt to measure collective mood-swing patterns. ${ }^{4}$ Here the focus will be on ambient air pollution, which is one of the most critical environmental stressors to which individuals are exposed, and has been found to be responsible for a broad spectrum of physical and psychological effects on human beings.

\section{The Role of the Trading Floor Community}

Though the studies mentioned in the previous section typically measure the levels of some environmental stimulus near the stock exchanges under investigation, investors are spread all across the corresponding countries. While addressing this issue, Goetzmann and Zhu (2005), using data about the trading activity of individual investors living in five major US cities, find no evidence of a link between local cloud cover and investment decisions; yet, the same authors detect a relationship between cloud cover in New York City and NYSE spreads, in turn suggesting that the mood effect documented in this stream of literature is likely to result from the behavior of market-makers or other agents who operate in or near the stock exchange. Based on these insights, here we try to shed more light on the possible mediating role played by the trading floor community. First, if changes in the environment have an impact on mood (and/or risk aversion), then one can construct a sufficiently precise proxy of trader mood (and/or risk aversion) by measuring an environmental stimulus at a monitoring station located near the exchange where

\footnotetext{
${ }^{4}$ These include temperature (Cao and Wei, 2005; Chang et al., 2006), humidity (Pardo and Valor, 2003; Chang et al., 2006), rain and snow (Hirshleifer and Shumway, 2003), and the seasonal light cycle (Kamstra et al., 2003). For a review of this literature, see Lucey and Dowling (2005).
} 
floor traders work. Second, there is evidence that the floor community (i.e. brokers and market-makers) has the ability to affect stock prices. For example, Sofianos and Werner (2000) claim that floor brokers not only execute trades on behalf of their customers, for they also collect information about buying/selling interest developing within the trading crowd and convey it back to their customers. As a result, based on the broker's feedback, individual investors may choose to modify the direction or the timing of their orders. The same authors argue that, when it comes to large orders, floor brokers have substantial margins of discretion in designing their execution strategy (e.g. buy as much as possible as fast as possible or break the order into smaller orders to minimize its market impact). Also, at the NYSE and MSE, for instance, investors can place so-called "market not held orders" that allow floor brokers to choose the timing of the order execution without any guarantee that the order itself will be filled. ${ }^{5}$ Saunders (1993) suggests that, beyond executing orders on behalf of their customers, floor traders "sometimes affect prices in attempts to exploit their own interests". In support of this view is the evidence that, in the last few decades, a nonnegligible number of NYSE floor brokers and market-makers has been charged with illegal conduct (Eaton, 1998; Johnson, 2005). With regard to market-makers, Madhavan and Smidt (1993) claim that the specialist not only provides liquidity but she is also an active investor who "seeks to maintain a long-term position in the stock consistent with his portfolio objectives". Consistently with this view, Goetzmann and Zhu (2005) suggest that weather-induced alterations in NYSE specialists' levels of risk-aversion may be responsible for their finding that bid-ask spreads seem to widen on cloudy days. Similarly, Limpaphayom et al. (2007), using data from the Chicago Mercantile Exchange, argue that effective bid-ask quotes suffer from weatherinduced biases, and disproportionally attract buy orders or sell orders from investors around the world. The next section will be devoted to examining the mechanisms through which air pollution affects people's moods and risk aversion, in turn influencing their decisions. Our empirical strategy relies on measuring air

\footnotetext{
${ }^{5}$ In this case, if the broker expects the stock price to fall, then she may wait to execute a buying order thinking that soon she will be able to obtain a better price for her customer (e.g. Garruccio and Greco, 2004; Maginn et al., 2007). 
pollution concentrations near the site hosting a given stock exchange, so that we can track the mood status (and/or degree of risk-aversion) of floor traders and examine whether it influences equity returns.

\section{Ambient Air Pollution and its Effects on Humans}

Air pollution is a phenomenon related to the presence of unhealthy particles and gases in the atmosphere. In this paper, most of the analysis is centered upon one specific constituent of air pollution, i.e. particulate matter $(\mathrm{PM})$, but some attention is also devoted to nitrogen oxides $\left(\mathrm{NO}_{\mathrm{x}}\right)$ and sulfur dioxide $\left(\mathrm{SO}_{2}\right){ }^{6}$ Throughout the paper, these pollutants are simply regarded as proxies for the level of air pollution. PM is made of "a complex mixture of solid and liquid particles of organic and inorganic substances suspended in the air" (WHO, 2003). TSP (total suspended particulates) measures all floating particles; $\mathrm{PM}_{10}$ and $\mathrm{PM}_{2.5}$ refer to particles with a diameter of less than $10 \mu \mathrm{m}$ and $2.5 \mu \mathrm{m}$, respectively. According to WHO (2006), the major share of TSP emissions at the European level is estimated to originate from "the combustion of solid fuels in small stoves in the residential and commercial sectors, followed by industrial emissions from energy combustion and manufacturing processes and from agricultural activities". The symbol $\mathrm{NO}_{\mathrm{x}}$ is used to represent the total concentration of nitric oxide (NO) plus nitrogen dioxide $\left(\mathrm{NO}_{2}\right)$. Although there are natural sources of $\mathrm{NO}_{\mathrm{x}}$ (e.g., volcanic action, forest fires), the combustion of fossil fuels is the major contributor in European urban areas (WHO, 2003). The most important natural sources of outdoor $\mathrm{SO}_{2}$ are volcanoes, forest fires, and oceans. As far as anthropogenic emissions are concerned, they can be mainly tracked back to residential heating, power plants, smelting of metals, paper manufacture and, residually, traffic (ARPA, 2003).

Though people spend the majority of their time indoors, WHO (2006) maintains that outdoor levels of air pollutants, typically measured through monitoring networks, are representative of population

\footnotetext{
${ }^{6}$ This choice is motivated by the fact that most psychological, toxicological, and epidemiological studies have focused on these measures. We consider multiple pollutants because their emission into the atmosphere originates from rather different sources, which allows us to address more convincingly some potential issues of endogeneity. 
exposure. The negative health effects that air pollution exerts on humans are well documented and go beyond the scope of the present paper. What is worthwhile to emphasize here is that, according to the reviews conducted on the subject, there appear to be no threshold concentrations below which the three pollutants in question have no effect on people (WHO, 2005; WHO, 2006). For the purposes of the present study it is also worthwhile to discuss the impact that exposure to air pollution may have on the bodily levels of cortisol. Cortisol is a hormone produced by the adrenal cortex, which is believed to play "a central role in the physiological and behavioral response to a physical challenge or psychological stressor" (Coates and Herbert, 2008). Previous studies have documented that urban air pollutants can trigger increases in bodily cortisol levels (e.g. Raff et al., 1985; Hsieh et al, 1992; Tomei et al., 2003). These findings are important because, as we will argue in the next section, there is evidence of a link between bodily cortisol levels, sensation seeking, and risk taking behavior. Apart from its well documented biophysical effects, air pollution has also been found to have an impact on humans' emotional wellbeing. Levy and Yagil (2011) summarize the rich literature on the relationship between air pollution and negative mood. Perceived effects, such as annoyance, have been detected in numerous studies (e.g., Forsberg et al., 1997; Klaeboe et al., 2000). Among the symptoms, feelings of fatigue, low mood and exhaustion have shown a significant association with air quality (Sagar et al., 2007). Lundberg (1996) finds that air pollutants can generate symptoms consistent with depression and anxiety. Bullinger (1989), using German data, estimates that daily increases in air pollution concentrations $\left(\mathrm{SO}_{2}\right)$ have a contemporaneous and lagged negative effect (up to a lag of 4 days) on mood. Similarly, Evans et al. (1988), using U.S. data, detect a positive link between ambient air pollutants and symptoms of anxiety. Along the same lines, Zeidner and Schechter (1988), and Chattopadhyay et al. (1995), using Israeli and Indian cross-sectional data, respectively, claim that exposure to acute levels of ambient air pollution is responsible for heightened levels of anxiety, depression, and tension. 


\section{Testable Hypotheses}

The hypotheses examined here builds upon evidence put forward in the fields of psychology, medicine, and finance. Based on a review of the relevant literature, we have identified two possible channels through which air pollution may affect trading decisions and, ultimately, stock returns: (1) as discussed in the previous section, increases in air pollution concentrations are believed to trigger mood deteriorations. At the same time, numerous experimental studies have shown that people in a negative (positive) mood tend to be more pessimistic (optimistic) and use probability estimates biased toward negative (positive) outcomes, which ultimately leads them to shy away from (take more) risk, all else equal. ${ }^{7}$ In other words, bad (good) mood causes people to systematically distort their probability weighting functions and, therefore, it affects their decisions involving risk. ${ }^{8}$ Our first hypothesis is therefore that, by leading to negative mood, a rise in air pollution levels induces individuals to be more pessimistic and reduces the demand for stocks, in turn having a negative influence on the direction and/or magnitude of equity returns, all else constant. (2) In section 3, we also discussed the findings of medical investigations that suggest that rises in air pollution concentrations may increase bodily levels of cortisol. This effect matters here because several psychological studies suggest that there exists a negative relationship between cortisol levels and risk taking behavior (Rosenblitt et al., 2001). More specifically, individuals who experience high cortisol levels are believed to be less likely to engage in sensation seeking behaviors (Mazur, 1995; Netter et al., 1996; Wang et al., 1997), where sensation seeking is defined as "pursuing and

\footnotetext{
${ }^{7}$ See Johnson and Tversky (1983), Kavanagh and Bower (1985), Mayer et al. (1992), Wright and Bower (1992), Constans and Matthews (1993), Mittal and Ross (1998), Fehr-Duda et al. (2006), and Kliger and Levy (2003, 2008).

${ }^{8}$ MacLeod and Campbell (1992) suggest that this effect may be mediated by the so-called "availability heuristic" proposed by Kahneman and Tversky (1973), according to which individuals "tend to base their estimates of the frequency or future probability of a given class of events on the ease with which instances of such events can be brought to mind". Indeed, the two authors find that mood changes "selectively facilitate the recall of personal memories that are emotionally congruent" with the new mood state and, as a result, the perceived probability of future negative (positive) events is higher in the low (high) mood condition. These results are also consistent with the findings of Kliger and Levy (2003, 2008), who, by extracting risk preferences from option prices, show that investors increase (decrease) their subjective probabilities of adverse events when they are in a bad (good) mood condition.
} 
taking risks in order to experience a variety of new sensations" (Zuckerman, 1979). ${ }^{9}$ In the present framework, we therefore hypothesize that a rise in air pollution leads to higher cortisol levels among market participants, in turn inducing them to behave more cautiously and reduce their demand for risky assets, which ultimately has a negative impact on the direction and/or magnitude of stock returns, all else equal. It should be noticed that both channels imply the existence of a negative relationship between air pollution concentrations and stock returns. As a result, our data do not allow us to distinguish between these two possible channels and further research would be needed in order to do so. We are able to test, though, whether the alleged relationship between air pollution and equity returns is mediated by the role that the trading floor community plays. Indeed, by tracking the air pollution concentrations near the site that hosts a given stock exchange we can construct a reasonable proxy for trader mood and/or degree of risk aversion and test whether such a proxy exhibits a systematic relationship with the performance of the relevant stock market indices. If the impact of local air pollution on stock returns mainly comes from the influence that air pollution has on the trading floor community's mood and/or degree of risk aversion, then, when examining stock exchanges that feature a trading floor, we should observe a statistically significant relationship between local air pollution and domestic equity returns. When examining stock exchanges that employ a floorless technology, instead, such a relationship should no longer exist. In this second case, finding a systematic relationship between local air pollution and stock returns would suggest that some other local agents (beyond the floor community) are also responsible for the existence of such a link. In order to test this second hypothesis, we initially exploit a natural experiment involving a change in the trading technology in place at the MSE, which moved from an open outcry system to an electronic and floorless one in the middle of the 1990's. To strengthen our results, later we also exploit the variation in trading technology across international stock exchanges, some of which feature a trading floor community and some of which employ a floorless trading system.

\footnotetext{
${ }^{9}$ This link is consistent with the findings of Coates and Herbert (2008), who experimentally measure the daily levels of such a hormone in a sample of male traders in the City of London under real working conditions. 


\section{Data}

Ambient air pollution concentrations are typically measured through a network of monitoring stations. ${ }^{10}$ Given the goal of the present study, one would like to employ a measure of air pollution that is highly representative of population exposure near the site that hosts the stock exchange at hand (where traders are physically located) and, at the same time, is very unlikely to be systematically associated with overall economic activity in the corresponding country. This way, that measure could be treated as an exogenous factor when explaining the behavior of stock returns. In the city of Milan, over the period under consideration, data about PM have been recorded by three monitors. According to APAT (2004), background monitoring stations normally represent overall city-wide exposure more closely than do roadside stations. In particular, background-urban-residential stations are employed to monitor air pollution levels within large urban areas. The measurements they make are not directly influenced by nearby traffic or industrial activities, and are meant to track air pollution mainly generated within the urban area under observation. As such, given the purpose of the present analysis, we collected data about $\mathrm{PM}, \mathrm{NO}_{\mathrm{x}}$, and $\mathrm{SO}_{2}$ levels, from January 2, 1989 through May 19, 2006, from the only station that is classified by APAT as a background station. ${ }^{11}$ It is worthwhile to stress that the measurements made by such a monitor are representative of population exposure in a small geographical area that precisely encircles the MSE. ${ }^{12}$ Particulate matter is measured as TSP from 01/02/1989 through 02/13/1998, and as $\mathrm{PM}_{10}$ thereafter. ${ }^{13}$ We measure all air pollution levels in $\mu \mathrm{g} / \mathrm{m}^{3}$. Table 1 reports some descriptive statistics.

Table 1 approximately here

\footnotetext{
${ }^{10}$ According to the guidelines set by the Italian Environmental Protection Agency (APAT, 2004), monitors are classified according to their type/purpose (Background, Industrial, Roadside), the area in which they are located (Urban, Suburban, Rural), and the characteristics of that same area (Residential, Commercial, Industrial, Agricultural).

${ }^{11}$ The monitoring station is located about 1.9 miles North-East of the MSE; it is classified as Background/Urban/Residential by APAT. We computed daily average values based on hourly data from $5 \mathrm{am}$ through $6 \mathrm{pm}$. When more than three hourly observations were missing, the daily value was counted as missing. Changing such a cut-off has no noticeable impact on the results.

${ }^{12}$ Typically, the ambient concentrations these monitors record are representative of areas covering few squared miles.

${ }^{13}$ Given that the conversion rate between these two quantities may fluctuate over time, we chose not to employ the $\mathrm{PM}_{10}$ values in the empirical analysis, thus reducing the sample period under investigation.
} 
In the province of Milan, as far as particulate matter (TSP) is concerned, road transport (i.e., traffic) is responsible for the largest amount of emissions, followed by residential and commercial heating, and combustion in manufacturing industry (ARPA Lombardia, 2001; 2002). Even greater appears to be the role of traffic in the release of nitrogen oxides, whereas energy production and heating are the main factors to blame for the emissions of sulfur dioxide.

For robustness purposes, we compute log stock returns for the Italian market using daily closing values of three MSE global indices, i.e., MIB Storico, Comit Global, and Datastream Italy-market, from January 2, 1989 through May 19, 2006. ${ }^{14}$ Some summary statistics are reported in Table 2.

Table 2 approximately here

To control for well-known calendar anomalies, we create a Monday dummy taking the value of 1 on Mondays and 0 otherwise (e.g., Gibbons and Hess, 1981). Also, we construct a Tax dummy that is assigned the value of 1 over the first seven days of January (e.g., Dyl, 1977). The other control variables employed in the econometric analysis come from several sources. ${ }^{15}$ Daily data about temperature and rain near the MSE are from ARPA Lombardia. ${ }^{16}$ The Seasonal Affective Disorder (SAD) effect is measured following the methodology proposed by Kamstra et al. (2003). Last, to control for the alleged behavioral effects of the lunar cycle (Yuan et al., 2006), we employ data about the lunar phases, obtained from NASA's web site, to create a FullMoon dummy variable taking the value of 1 up to three days before and after each Full Moon date and 0 otherwise. Analogously, we construct a NewMoon dummy that is assigned the value of 1 up to three days before and after each New Moon date.

\footnotetext{
${ }^{14}$ Currently, the number of stocks included in these three value-weighted indices varies from approximately 150 (MIB) to about 240 (Comit).

${ }^{15}$ These are the behavioral variables that are typically included in this stream of literature.

${ }^{16}$ Daily temperature values, in Celsius degrees, are computed as the mean of maximum and minimum daily temperatures. Rain is measured in mm. Both time series begin on January 2, 1989. 


\section{Empirical Analysis}

\subsection{Baseline Model}

As previously mentioned, the MSE experienced an institutional change in the middle of the 1990's, the shift being from a traditional floor trading system to an electronic and floorless one. ${ }^{17}$ The floor trading system was abandoned on April 15, 1994 (Pia, 1994). Until that day, traders were physically present on the trading floor of the MSE and, as such, their exposure to air pollution was accurately tracked by the monitoring station employed in the current study. If the behavioral hypothesis constructed in the previous sections is correct, then, during this period, air pollution concentrations should be a good proxy for trader mood and/or degree of risk aversion. As a result, such a proxy should exhibit a negative relationship with the behavior of Italian stock returns. Also, if the relationship between local air pollution and Italian equity returns is mainly mediated by the influence that the former exerts on the trading floor community, then such a relationship should no longer appear after April 15, 1994, when the trading floor technology was replaced and traders began to operate remotely from many other places featuring dissimilar air pollution concentrations. On the other hand, if some other category of local agents is responsible for the relationship between local air pollution and Italian stock returns, then the air pollution effect should not disappear in the second era and we should still detect a systematic correlation between the two variables of interest. For example, the mediating role might be played by a sizable group of brokerage houses and/or financial institutions that are clustered around the original site of the MSE and maintain their location after the trading switch. Yet, observing a decline in the magnitude of the air pollution effect in the second era would provide some support to the view that at least part of said effect arises through the behavior of the trading floor community.

\footnotetext{
${ }^{17}$ The city of Milan hosts the main (and now sole) Italian stock exchange. Three main reasons led to the choice of the Italian market for our analysis. First, Milan is among the cities that have been suffering the most from the air pollution phenomenon, at least within the industrialized countries (Shulevitz, 1989; Rosenthal, 2007). Second, data about air pollution levels near the MSE cover a long time span. Third, as just pointed out, the MSE underwent an institutional change from an open outcry system to an electronic and delocalized one, which provides a useful identification strategy.
} 
In the spirit of Hirshleifer and Shumway (2003), for each stock market index we estimate by maximum likelihood a binary logit model of the form

$$
P\left(r_{t}>0\right)=\frac{e^{\mu_{P M} P M_{t-1}+X_{t} \beta}}{1+e^{\mu_{P M} P M_{t-1}+X_{t} \beta}}
$$

where

$$
\begin{gathered}
\mathrm{X}_{t} \beta=\beta_{1}+\sum_{j=2}^{P} \beta_{j} R_{t-j}+\beta_{\text {SAD }} \text { SAD }_{t}+\beta_{\text {Fall }} \text { Fall }_{t}+\beta_{\text {FullMoon }} \text { FullMoon }_{t}+\beta_{\text {NewMoon }} \text { NewMoon }_{t} \\
+\beta_{\text {Monday }} \text { Monday }_{t}+\beta_{\text {Tax }} \text { Tax }_{t}+\beta_{\text {Temp }} \text { Temp }_{t}+\beta_{\text {Rain }} D_{t}^{\text {Rain }}+\sum_{i=1}^{11} \gamma_{i} \text { Month }_{i t} \\
R_{t}= \begin{cases}1 ; & \text { if } r_{t}>0 \\
0 ; & \text { otherwise }\end{cases}
\end{gathered}
$$

In the model above, $r_{t}$ represents the daily return of a given MSE index between day $t-1$ and day $t, P M_{t-1}$ measures the daily ambient concentration of particulate matter near the MSE on day $t-1, D_{t}^{\text {Rain }}$ is a dummy that takes the value of 1 if a positive amount of rain has fallen near the MSE on day $t, \operatorname{Temp}_{t}$ is the average temperature near the MSE on day $t$, and $M_{0}$ th $h_{i}$ is a dummy that takes the value of 1 in calendar month $i$ and 0 otherwise. The remaining variables have the meaning previously specified. ${ }^{18}$

All the estimated marginal effects are reported in Table 3, and they tell a consistent story. Focusing on the first sub-period, 1989-1994, for all three market indices there is evidence of a negative relationship between the level of particulate matter on day $t-1$ and the probability that stock returns will be positive on day $t$. More specifically, we find that a $10 \mu \mathrm{g} / \mathrm{m}^{3}$ (one standard deviation) increase in the concentrations of particulate matter near the MSE reduces the probability that Italian equity returns will be positive on the following trading day by approximately $1.5 \%(7 \%)$. The coefficient on the air pollution variable is statistically different from zero at the $1 \%$ level across the three indices. Moving to the second sub-period,

\footnotetext{
18 A flexible number of lagged returns (in the form of the binary variable $R_{t}$ ) is included in each regression, when statistically significant. 
1994-1998, we can notice that the coefficient on the pollution variable is estimated to be positive in all three instances, yet definitely statistically insignificant. We can also notice that the corresponding standard errors seem to be larger than the ones computed for the first market era. When we compare the estimated coefficients between the two eras, in the case of the Comit and MIB indices we can reject the null hypothesis that the marginal effect of air pollution is the same in the two sub-periods at the $10 \%$ confidence level. This provides some preliminary evidence that the air pollution effect was stronger during the period in which trading was conducted on the floor and, as such, it supports the view that the trading floor community plays a mediating role between local air pollution and equity returns. Yet, at this stage, we cannot rule out alternative explanations. For instance, it seems the case that pollution levels were generally lower during the second sub-period and, as such, one may still wonder whether our failure to detect a negative relationship between air pollution and stock returns in such a sub-period is due to the diminished effect of the former on human beings. ${ }^{19}$ As far as the other explanatory variables are concerned, a "Monday effect" seems to be present in both sub-periods, whereas there is only minor evidence that the lunar cycle, the tax dummy, and local temperature are systematically associated with equity returns. The patterns that emerge when the remaining explanatory variables are considered do not seem to reveal any systematic relationship with the dependent variable.

Table 3 approximately here

\subsection{Prolonged Exposure to High Levels of Air Pollution}

Based on the medical and psychological literature presented in the previous sections, we speculate that the effects of a prolonged exposure to high levels of air pollution might, to some extent, add to each

\footnotetext{
${ }^{19}$ Such a reduction in air pollution levels seems to be attributable to several factors: (1) the introduction of European emission standards that set progressively lower limits for exhaust emissions of new vehicles sold in E.U. member states, (2) technological improvements, (3) the renovation of residential and commercial heating systems. These factors are mentioned by ARPA Lombardia on its web site (http://www.arpalombardia.it/).
} 
other. In a review of the effects of air pollution on physical well-being, Schwartz (2000) argues that the effects of exposure may be visible over several subsequent days and claims that "most of the studies that considered associations with a multi-day moving average found that a 2- or 3-day moving average of air pollution has fit better than any single day's pollution or longer moving average". To explore this idea, we construct a three-day moving average of the air pollution proxy as follows

$$
P M_{t-1}^{\text {Average }}=\frac{1}{3} \sum_{j=1}^{3} P M_{t-j}
$$

We then replace $P M_{t-1}$ with said three-day moving average in model [1] and re-estimate the model. The relevant coefficients are reported in Table $4 .{ }^{20}$ Once again, the picture that emerges tells a consistent story and is supportive of the hypothesis under investigation. The sign of the air pollution effect is estimated to be negative for all three indices when the first-subsample is considered. In particular, a $10 \mu \mathrm{g} / \mathrm{m}^{3}$ (one standard deviation) rise in the average level of particulate matter between day $t-3$ and $t-1$ is estimated to reduce the probability that stock returns will be positive on day $t$ by about $2 \%(7.8 \%)$. Such a point estimate is slightly larger, in absolute value, than the one illustrated in the previous section, yet there is not enough statistical evidence to conclude that the impact of air pollution on trading decisions is stronger when air pollution levels have been high for a few days in a row. When the second sub-sample (1994-1998) is analyzed, the estimated coefficient on the pollution proxy is statistically insignificant in all three instances. In the case of the Comit and MIB indices, we can reject the null hypothesis that the marginal effect of air pollution is the same in the two sub-periods at the 5\% confidence level. Keeping in mind the limitations discussed earlier, these results are consistent with the interpretation that at least part of the air pollution effect on stock returns arises through its impact on the trading floor community. Most of the remaining explanatory variables reveal the same patterns discussed earlier. However, here there seems to be more evidence that equity returns are more likely to be negative in the fall (second sub-period). When it comes to the lunar phases,

\footnotetext{
${ }^{20}$ When one or more daily observations were missing between day $t-3$ and $t-1$, the three-day moving average variable was assigned a missing value. 
oddly enough, in the first sub-sample there appears to be a negative marginal effect of the full moon on the direction of stock returns, whereas a positive effect is found when the second sub-sample is examined.

Table 4 approximately here

\subsection{Robustness Checks}

To test whether the previous results are driven by a few extreme high-pollution days that may happen to coincide with other events causing the stock market to perform poorly, we re-estimate model [1] excluding the $1 \%$ of observations with the highest pollution concentrations. In practice, we do so by including in the model a dummy variable that takes the value of 1 on day $t$ when one of these extreme highpollution events occurs on day $t$, and zero otherwise. We then repeat this exercise using a $3 \%$ and $5 \%$ cutoff, respectively. The findings reveal no noticeable change from a qualitative perspective. Using model [1] we have tested whether the direction of an index returns is related to local air pollution. It is also interesting to determine whether the magnitude of the index returns is related to such a factor. In order to shed light on this issue, we estimate the following GARCH $(1,1)$ model using the Huber-White sandwich robust estimator of variance (Huber, 1967; White, 1980):

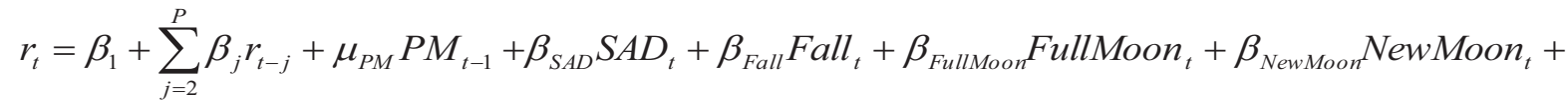

$$
\begin{aligned}
& +\beta_{\text {Monday }} \text { Monday }_{t}+\beta_{\text {Tax }} \text { Tax }_{t}+\beta_{\text {Temp }} \text { Temp }_{t}+\beta_{\text {Rain }} D_{t}^{\text {Rain }}+\sum_{i=1}^{11} \gamma_{i} \text { Month }_{i t}+\varepsilon_{t} \\
& \varepsilon_{t}=\sigma_{t} z_{t} \quad z_{t} \sim \operatorname{iid} N(0,1) \\
& \sigma^{2}=\alpha_{0}+\alpha_{1} \varepsilon_{t-1}^{2}+\alpha_{2} \sigma_{t-1}^{2}
\end{aligned}
$$

The results, not reported here due to space limitations, are consistent with the outcomes of the previous steps. More specifically, we find evidence of a statistically significant negative relationship between air pollution levels on day $t-1$ and stock returns on day $t$ when the first sub-sample (1989-1994) is considered. 
The marginal effect of air pollution is estimated to be similar across the three market indices, and it suggests that a $10 \mu \mathrm{g} / \mathrm{m}^{3}$ (one standard deviation) increase in particulate matter on day $t-1$ is expected to cause equity returns to be about 3 (14) basis points lower than average on day $t$, all else equal. Analogous results are obtained when the one-day lagged pollution proxy, $P M_{t-1}$, is replaced by the three-day air pollution moving average defined in formula [3]. On the other hand, when the second sub-sample (1994-1998) is examined, the coefficient on the air pollution proxy is estimated to be statistically insignificant for all three market indices. ${ }^{21}$ Last, we test whether the negative relationship between local air pollution and the magnitude of equity returns is mediated by the influence that the former may exert on the variance of equity returns. We do so by inserting the pollution proxy into the conditional variance equation of model [4], and we find no evidence that increases in air pollution concentrations are followed by increases in the volatility of returns.

\subsection{Instrumental Variables Estimation}

In the present setting some potential issues of endogeneity arise because, at the country level, there is a connection between economic activity and the dynamics of air pollution. Some air pollution comes from natural sources, yet most pollution is the result of human activity. Secondly, airborne contaminants are also known for having a negative feedback onto economic activity via the social costs (externalities) they generate. These costs take the form of premature mortality (WHO, 2006), reduced productivity, work loss, and "restricted activity days" due to the long-term health effects of pollution, and damage to the agricultural sector. $^{22}$ We start addressing these issues by emphasizing that the air pollution data employed in our analysis (collected from a single monitoring station near the MSE) are representative of human exposure in an area that merely covers few squared miles around the MSE, which means they do not represent a global measure of air pollution in the Italian peninsula. Nevertheless, in order to render our analysis more rigorous,

\footnotetext{
${ }^{21}$ As an additional control, we included in both model [1] and [4] a variable that captures temporary disturbances of the Earth's magnetosphere, as proposed by Krivelyova and Robotti (2003). Our results were essentially unchanged.

${ }^{22}$ See, for example, Hausman et al. (1984), Zuidema and Nentjes (1997), Östblom and Samakovlis (2004), and Henderson (1996). $-17-$
} 
we also address these endogeneity concerns by carrying out an IV estimation. As it is well understood, ambient air pollution is deeply affected by meteorological conditions. As such, a set of meteorological parameters can represent a valuable set of instruments. In particular, our instruments consist of: (1) wind speed, and (2) atmospheric pressure, both measured near the MSE. ${ }^{23}$ The intuition behind this identification strategy is straightforward. While high wind speed and low atmospheric pressure near the MSE both contribute to reduce the air pollution concentrations to which floor traders are exposed (e.g., Campbell and Gipps, 1975; Mossetti et al., 2005), one can hardly maintain that they also directly affect overall Italian economic activity. Similarly, there seems to be no theoretical justification for asserting that lagged values of said meteorological variables bear any systematic relationship with Italian stock returns. ${ }^{24}$ We initially employ a 2SLS technique and estimate a first-stage regression equation of the form

$$
P M_{t-1}=\mathrm{X}_{t} \beta+\sum_{k=2}^{3} \lambda_{k} \text { Wind }_{t-k}+\sum_{k=2}^{3} \pi_{k} \text { Pressure }_{t-k}+\varepsilon_{t}
$$

where $X_{t} \beta$ has been defined in equation [2], Wind $d_{t}$ measures wind speed near the MSE on day $t$, and Pressure $_{t}$ captures the atmospheric pressure near the MSE on day $t$. The second-stage model, which is a linear probability model, employs fitted air pollution data $\left(P M_{t-1}^{*}\right)$ from the first-stage model and takes the following form

$$
I\left(r_{t}>0\right)=\mu_{P M} P M_{t-1}^{*}+\mathrm{X}_{t} \beta+\varepsilon_{t}
$$

where $I\left(r_{t}>0\right)$ is an indicator variable that is one when stock returns are positive. The first-stage estimates (not reported here due to space limitations) confirm that these instruments bear a systematic

\footnotetext{
${ }^{23}$ Such data come from the same monitoring station from which we obtained air pollution data.

${ }^{24}$ We use lagged values here because, in principle, these environmental factors might act as mood proxies and, thus, they might have a contemporaneous relationship with equity returns. However, the following should be kept in mind: first, no study has thus far documented a link between local atmospheric pressure and stock returns; second, when we tried to include contemporaneous wind speed as a regressor in model [1], no significant marginal effect on equity returns was detected. In the first-stage equation estimated here, we include these two meteorological parameters with two- and three-day lags. The results are robust to the choice of the lag structure.
} 
relationship with air pollution near the MSE, proxied by particulate matter (both lags are generally significant at least at the $5 \%$ confidence level). Table 5 collects the second-stage estimates. This time, the picture that emerges is less clear-cut than in the previous sections. When the first sub-sample is considered, in the case of the Comit and Datastream indices there is still some evidence that an increase in air pollution reduces the probability that returns will be positive on the following trading day. In both instances the coefficient on the air pollution proxy is estimated to be negative and similar in magnitude to the outcome of regression [1]. In both cases we can reject the null hypothesis that such a coefficient is equal to zero at the $10 \%$ confidence level. The evidence is weaker in the case of the MIB index ( $p$-value $=0.16$ ), yet even in this case the sign of the marginal effect of air pollution conforms to our expectations. When the second subsample is examined, the coefficients on the pollution proxy are estimated to be negative across the three market indices. Based on their point estimates, such coefficients appear to be even slightly larger (in absolute value) than in the case of the first sub-sample. However, the corresponding standard errors are also larger, so that none of said coefficients is statistically different from zero. As a result, though this IV estimation model provides some support to our air pollution hypothesis, it does not allow us to draw any firm conclusion about whether the pollution effect disappeared or weakened after the MSE trading floor was abandoned. As far as the remaining explanatory variables are concerned, we still find strong evidence of a Monday effect in both sub-periods, and now we also find some evidence of a relationship between local temperature and equity returns in the first sub-sample, but not in the second. We obtained similar results when we repeated the 2SLS procedure after replacing the dependent variable in equation [5] with the threeday air pollution moving average defined in formula [3]. The relevant coefficients are reported in Table 6.

Table 5 and Table 6 approximately here

We also repeated this kind of analysis using Amemiya (1978)'s Generalized Least Squares (AGLS) estimator and a probit model. In this context, the endogenous variable is treated as a linear function of the instruments and the exogenous variables in the first-stage regression (i.e. equation [5]). The prediction from 
the first stage is then included as an explanatory variable in the binary probit model and the standard errors are corrected using Newey (1987)'s approach. ${ }^{25}$ The results we obtained were practically identical to the ones we found using the linear probability model discussed above and, as such, they are not reported here.

\subsection{Alternative Air Pollution Proxies}

As emphasized during the literature review, medical research has been hesitant in attributing specific health effects to individual pollutants, for most epidemiological studies have to deal with complex mixtures of environmental toxins whose specific (and synergistic) effects are not yet completely understood. Therefore, it is useful to examine whether the air pollution effect, detected in the previous sections using PM as an indicator, can also be identified when alternative pollution proxies are employed. Second, daily data about ambient concentrations of nitrogen oxides and sulfur dioxide near the MSE are available for a longer time span than PM, their time series extending up to 2006. Third, employing a set of different proxies may help shed additional light on the possible endogeneity issue previously mentioned. As discussed in section 5, the direct emissions of $\mathrm{PM}, \mathrm{NO}_{\mathrm{x}}$, and $\mathrm{SO}_{2}$ can be credited to rather dissimilar sets of sources. While the major contributor to the emissions of particulate matter and $\mathrm{NO}_{\mathrm{x}}$ is road transport, residential heating systems and power plants produce the lion's share when it comes to $\mathrm{SO}_{2}$. Showing that air pollution near the MSE, independently of its sources, is systematically associated with Italian stock returns would strengthen the support for the behavioral hypothesis tested in this study. Following this line of reasoning, we repeat the IV estimation procedure shown above, this time employing either $\mathrm{NO}_{\mathrm{x}}$ or $\mathrm{SO}_{2}$ in place of PM as the dependent variable in model [5] (and its fitted values in model [6]). We then replicate the same exercise using the three-day moving average of either $\mathrm{NO}_{\mathrm{x}}$ or $\mathrm{SO}_{2}$ in place of $\mathrm{PM}$, according to the following formulas

\footnotetext{
${ }^{25}$ The computations were made using the "ivprob" routine in STATA (see Harkness, 2001). 


$$
N O x_{t-1}^{\text {Average }}=\frac{1}{3} \sum_{j=1}^{3} N O x_{t-j} \quad S O 2_{t-1}^{\text {Average }}=\frac{1}{3} \sum_{j=1}^{3} S O 2_{t-j}
$$

The outcomes are contained in Table 7 and Table 8, respectively (due to space limitations we only report the coefficients on the pertinent air pollution variables). Beginning with $\mathrm{NO}_{\mathrm{x}}$, we can see that the sign of the coefficient on the one-day lagged pollution variable (Panel A) is estimated to be negative in both subperiods, and the point estimates for the first sub-period appear to be larger in size (in absolute value). However, none of the coefficients is statistically different from zero. More evidence is found when the three-day pollution moving average is employed as an explanatory variable (Panel B). In this case, when considering the first sub-sample, we estimate that a $10 \mu \mathrm{g} / \mathrm{m}^{3}$ (one standard deviation) rise in the average level of $\mathrm{NO}_{\mathrm{x}}$ between day $t-3$ and $t-1$ reduces the probability that equity returns will be positive on day $t$ by approximately $0.5 \%(13 \%)$. Such a marginal effect is statistically different from zero at least at the $10 \%$ confidence level for all three market indices. On the other hand, when examining the second sub-sample, we notice that the three relevant coefficients are close to zero and are not statistically significant. Keeping in mind the limitations discussed earlier, such a pattern is consistent with the interpretation that at least part of the pollution effect arises through the behavior of the trading floor community.

Table 7 and

Table 8 approximately here

Moving to the third pollutant, $\mathrm{SO}_{2}$, in the first sub-period we find that the estimated coefficients on the pollution proxy are negative in both Panel A and Panel B, yet statistical significance is never achieved. This might be due to the relatively small number of observations in the first sub-sample, which is a consequence of many missing $\mathrm{SO}_{2}$ observations. When the second sub-sample is examined, the relevant coefficients are still negative, and despite the large number of observations available, they are still not statistically different from zero. As such, there is no evidence of a link between $\mathrm{SO}_{2}$ levels and equity returns. 


\section{International Evidence}

It is obviously of interest to verify whether the empirical patterns documented in the previous sections are also present in other stock markets, especially in the ones that have not yet abandoned the trading floor technology. Producing evidence of an air pollution effect with regard to stock exchanges that employ a floor and, at the same time, failing to find any evidence in connection with floorless exchanges would strengthen the support for the hypothesis that such an effect is mainly mediated by the impact that local air pollution exerts on the trading floor community. To explore this matter, we focus on a group of major international stock markets and try to include in the study most of the exchanges that, during the sample period, employed a trading floor. ${ }^{26}$ The final sample contains data for the United States, Canada, Ireland, Spain, UK, France, Germany, China, and Australia. For each of these countries' leading stock exchanges we collected daily local air pollution data, equity returns, and control variables according to the methodology described in the appendix. Some descriptive statistics are reported in Table 9 and Table 10.

Table 9 and Table 10 approximately here

For each stock exchange $i$ and each stock market index $j$, we estimate by maximum likelihood a binary logit model of the form

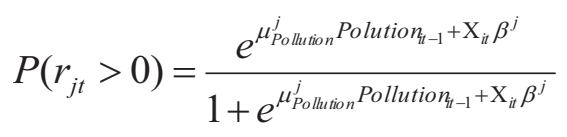

where $X_{i} \beta^{i}$ has been defined in equation [2], and Pollution $_{i t-1}$ represents the value of the proxy used to track air pollution levels near stock exchange $i$ on day $t-1$. The results are reported in Table 11 and tell a consistent story (due to space limitations we only display the coefficients on the relevant air pollution proxies). When the group of stock exchanges with a trading floor is considered, there is widespread

\footnotetext{
${ }^{26}$ To the best of our knowledge, the only two that are missing are the Hong Kong Stock Exchange and Buenos Aires Stock Exchange, for which air pollution data could not be obtained. Our data cover the period up to the end of 2008.
} 
evidence of a negative relationship between local air pollution levels and the performance of the corresponding market indices. For example, in the case of the U.S. stock market, when the concentration of particulate matter near Wall Street increases by $10 \mu \mathrm{g} / \mathrm{m}^{3}$ (one standard deviation) on day $t-1$, we estimate that the probability that the S\&P500 index will rise on day $t$ decreases by $4 \%(3.3 \%)$, which corroborates the findings of Levy and Yagil (2011). The effect is highly statistically significant, as it happens to be the case for most of the other markets, indices, and pollution proxies analyzed. ${ }^{27}$ In terms of economic significance, the size of this effect seems smaller (in absolute value) when the other countries in this group are considered. Yet, it should be noticed that the variability of PM levels is higher in Spain, Germany, China, and Ireland, so that the size of the marginal effect of a one standard deviation increase in PM levels is fairly uniform across countries and indices. Overall, the magnitude of such an effect appears to be economically significant but not particularly large.

Table 11 approximately here

When the group of floorless exchanges is examined, no statistical evidence seems to surface of a relationship between local air pollution and the behavior of stock returns. Though the coefficients on the pollution proxies of interest happen to be negative in a few occurrences, standard statistical significance is never approached. Special attention should be devoted to the Irish case, as this market experienced a switch from floor trading to electronic and delocalized trading on June 6,2000 , thus generating an additional natural experiment. We can notice that the coefficients on the pollution proxies are estimated to be negative in both sub-periods, yet they are statistically significant only in the first sub-period. In the second subsample the point estimates seem to be even larger (in absolute value) than in the first one; however, given

\footnotetext{
${ }^{27}$ We find no statistical evidence of a link between PM and stock returns for Germany and China. A possible reason for this is that the sample size is relatively small. In the case of Shanghai, some observers have also raised concerns about the reliability of the PM data (e.g. Andrews, 2008). 
the size of the corresponding standard errors, here we are not able to draw any solid inferences about the impact that the trading system switch had on the magnitude of the air pollution effect. ${ }^{28}$

Taken together, this multi-country evidence seems to be consistent with our air pollution hypothesis and also provides some preliminary support to the hypothesis that the air pollution effect is at least partly mediated by the influence that local air pollution exerts on the trading floor community. At this stage, we cannot rule out some alternative explanations, though. Our analysis of the floorless exchanges is based on relatively recent (and short) samples, and it is reasonable to assume that air pollution levels were lower in the recent past than in the distant past. As such, the influence of air pollution on mood and/or risk aversion might have been weaker in the recent past, which implies that detecting a pollution effect would be harder when employing a recent sample of data. This means that, based on our data, we cannot exclude that some other agents located in the city that hosts a stock exchange (e.g. brokerage houses, financial institutions, news providers) may also be responsible for the relationship that we seem to observe between local air pollution and the performance of the corresponding stock market indices.

\section{Conclusion}

Researchers have documented that some environmental stimuli in the city that hosts a stock exchange influence the behavior of the corresponding stock market returns. Such an effect is supposed to take place through the impact that said stimuli may have on the mood and/or risk aversion of some agents that are physically located in the city hosting the exchange. The present investigation has focused on air pollution and on its role in affecting people's decisions through its impact on mood (channel 1) and/or risk aversion (channel 2). Based on the evidence produced in the fields of medicine and psychology, we argued that daily increases in ambient air pollution may deteriorate individuals' mood and/or intensify their risk

\footnotetext{
${ }^{28}$ The patterns that we obtain when we repeat the analysis of this sample of international stock exchanges using a three-day air pollution moving average in place of the one-day lagged pollution variable are very similar. The only difference is that in this case the coefficients for the U.S. market are only marginally significant. Due to space limitations, here we do not report the corresponding outcomes. 
aversion, in turn distorting their probability estimates of future events and inducing them to reduce their demand for risky assets. The final outcome of such a chain of events would be a negative impact on the direction of stock returns and/or on their magnitude. We also conjectured that the relationship between air pollution levels near a stock exchange and equity returns might be mediated by the influence that the former exert on the trading floor community. To test our hypothesis we initially employed data from the MSE, and exploited the institutional change that its trading technology experienced from a floor system to an electronic and floorless one. We found extensive evidence of an air pollution effect consistent with our hypothesis when the floor period was considered; more specifically, a rise in air pollution was estimated to have a negative marginal effect on both the direction and size of equity returns. Yet, the evidence in support of a disappearance (or weakening) of such an effect after the trading system switch was mixed. In particular, we cannot rule out the possibility that our inability to detect an air pollution effect in the second era is the result of a general reduction in air pollution levels that took place concurrently with the trading system switch. In order to strengthen our results, we also examined a fairly large sample of international stock exchanges and exploited the variation in trading technologies across such exchanges. When the group of exchanges featuring a trading floor community was assessed, we detected an air pollution effect for most of the market indices and air pollution proxies considered. No statistically significant relationship was found, instead, when the group of floorless exchanges was examined. Such a pattern is consistent with the interpretation that the air pollution effect is at least partly mediated by the impact of local air pollution on the trading floor community's mood and/or risk aversion. Nevertheless, we acknowledge that our data about the floorless exchanges mainly come from the recent past, so that we cannot exclude that our inability to detect an air pollution effect in such instances is the result of a better air quality in recent times. As a result, we cannot rule out that some other categories of local agents (e.g. brokerage houses, news providers) may also play a mediating role in the relationship that we found between local air pollution and the performance of the corresponding stock market indices. It should also be pointed out that, both in the case of the Italian market and the sample of international markets, our data did not allow us to distinguish between the two 
possible channels (i.e. mood vs. risk aversion) through which air pollution might influence trading decisions. More research and perhaps some lab experiments are needed in order to disentangle the two possible effects. 


\section{References}

Ackert L., B. Church, and R. Deaves (2003). Emotion and financial markets, Federal Reserve Bank of Atlanta Economic Review, Second Quarter 2003, pp. 33-41.

Amemiya T. (1978). The estimation of a simultaneous equation generalized probit model, Econometrica, 46, pp. 1193-1205.

Andrews S. Q. (2008). Inconsistencies in air quality metrics: "Blue Sky" days and PM10 concentrations in Beijing, Environmental Research Letters, 3, Online Edition.

APAT - Agenzia per la Protezione dell'Ambiente e per i servizi Tecnici (2004). Linee Guida Per La Predisposizione Delle Reti Di Monitoraggio Della Qualità Dell'aria In Italia, Roma.

Areni C. S. and D. Kim (1993). The influence of background music on shopping behavior: Classical versus top-forty music in a wine store, Advances in Consumer Research, 20, pp. 336-340.

ARPA Lombardia - Regione Lombardia (2001). Rapporto sulla qualità dell'aria di Milano e provincia: Anno 2001.

ARPA Lombardia - Regione Lombardia (2002). Rapporto sulla qualità dell'aria di Milano e provincia: Anno 2002.

ARPA Lombardia - Regione Lombardia (2003), INEMAR, Inventario Emissioni in Atmosfera: emissioni in regione Lombardia nell'anno 2001, ARPA Lombardia Settore Aria, Regione Lombardia DG Qualità dell'Ambiente.

Au K., Chan F., Wang D., and I. Vertinsky (2003). Mood in foreign exchange trading: Cognitive processes and performance, Organizational Behavior and Human Decision Processes, 91, pp. 322-338.

Bruner G. C. (1990). Music, mood, and marketing, Journal of Marketing, 54 (4), pp. 94-104.

Bullinger M. (1989). Psychological effects of air pollution on healthy residents-A time-series approach, Journal of Environmental Psychology, 9 (2), pp. 103-118.

Byrne, D. and G. L. A. Clore (1970). A reinforcement model of evaluative responses, Personality, 1, pp. 103-128.

Campbell N. A. and J. Gipps (1975). The Influence of Meteorological Conditions on Air Pollution, Australian Science Teacher Journal, 21 (2), pp. 67-73.

Cao M. and J. Wei (2005). Stock market returns: A note on temperature anomaly, Journal of Banking and Finance, 29, pp. 1559-1573.

Chang T., C. Nieh, M. Yang, and T. Yang (2006). Are stock market returns related to the weather effects? Empirical evidence from Taiwan, Physica A, 364, pp. 343-354. 
Chattopadhyay P. K., B. Som, and P. Mukhopadhyay (1995). Air Pollution And Health Hazards In Human Subjects: Physiological And Self-Report Indices, Journal of Environmental Psychology, 15, pp. 327-331.

Coates J. and J. Herbert (2008). Endogenous steroids and financial risk taking on a London trading floor, Proceedings of the National Academy of Sciences, 105 (16), pp. 6167-6172.

Constans, J. J. and Mathews, A. M. (1993). Mood and the subjective risk of future events, Cognition and Emotion 7(6), pp. 545-560.

Damasio A. (1994). Descartes’ Error: Emotion, Reason, and the Human Brain. New York: Putnam.

Dyl E. (1977). Capital gain taxation and year-end stock market behavior, Journal of Finance, 32, pp. 165175.

Eaton L. (1998). 'Big Board Floor Brokers Charged in Illegal Profits', The New York Times, February 26.

Evans G. W., S. D. Colome, and D. F. Shearer (1988). Psychological reactions to air pollution, Environmental Research, 45 (1), pp. 1-15.

Fehr-Duda H., Schürer M. and R. Schubert (2006). What Determines the Shape of the Probability Weighting Function?, Working Paper 06/54, CER-ETH - Center of Economic Research at ETH Zurich.

Field A. P. and H. Schorah (2007). The verbal information pathway to fear and heart rate changes in children, Journal of Child Psychology and Psychiatry, OnlineEarly Article.

Forgas J. P. (1995). Mood and judgment: The affect infusion model (Aim), Psychological Bulletin, 117, pp. $39-66$.

Forsberg B., N. Stjernberg, and S. Wall (1997). People can detect poor air quality well below guideline concentrations: A prevalence study of annoyance reactions and air pollution from traffic, Occupational and Environmental Medicine , 54 (1), pp. 44-48.

Frank, Robert H. 1988. Passions within reason. New York: Norton.

Frijda N. (1988). The laws of emotion, Cognition and Emotion, 1, pp. 235- 258.

Garruccio R. and A. Greco (2004). Le grida: memoria, epica, narrazione della Borsa di Milano (19451995), Borsa valori di Milano. Comitato direttivo degli agenti di cambio. Published by Rubbettino Editore srl.

Gibbons M. R. and P. Hess (1981). Day of the Week Effects and Asset Returns, The Journal of Business, 54 (4), pp. 579-596.

Goetzmann W. N. and N. Zhu (2005). Rain or Shine: Where is the Weather Effect?, European Financial Management, 11 (5), pp. 559-578. 
Gulas C. S. and P. H. Bloch (1995). Right under our noses: Ambient scent and consumer responses, Journal of Business and Psychology, 10, pp. 87-98.

Harkness J. (2001). IVPROB-IVTOBIT: Stata modules to estimate instrumental variables probit and tobit. Statistical Software Components from Boston College Department of Economics.

Hausmann J.A., B. Ostro, and D.A. Wise (1984). Air Pollution and Lost Work, Working Paper No. 1263, National Bureau of Economic Research, Cambridge.

Henderson J. V. (1996). Effects of air quality regulations, American Economic Review, 86 (4), pp. 789-813.

Hirshleifer D. and T. Shumway (2003). Good day sunshine: Stock returns and the weather, Journal of Finance, 58 (3), pp. 1009-1032.

Hsieh G.C., Sharma R.P. and R. D. Parker (1992). Hypothalamicpituitary- adrenocortical axis activity and immune function after oral exposure to benzene and toluene, Immunopharmacology, 21, pp. 23-31.

Huber P. J. (1967). The behavior of maximum likelihood estimates under non-standard conditions, Proceeding of the Fifth Berkeley Symposium on Mathematical Statistics and Probability, 1, pp. 221233.

Isen A. M., T. E. Shalker, M. Clark, and L. Karp (1978). Affect, accessibility of material in memory, and behavior: A cognitive loop?, Journal of Personality and Social Psychology, 36, pp. 1-12.

Kahneman D. and A. Tversky (1973). Availability: a heuristic for judging frequency and probability, Cognitive Psychology, 5, pp. 207-232.

Kamstra M. J., L. A. Kramer, and M. D. Levi (2003). Winter Blues: A sad stock market cycle, American Economic Review, 93 (1), pp. 324-343.

Kavanagh, D. and Bower, G. (1985), Mood and self-efficacy: Impact of joy and sadness on risk as feeling perceived capabilities, Cognitive Therapy and Research, 9, pp. 507-525.

Klaeboe R., M. Kolbenstvedt, J. Clench-Aas, and A. Bartonova, (2000). Oslo traffic study—part 1: an integrated approach to assess the combined effects of noise and air pollution on annoyance, Atmospheric Environment, 34 (27), pp. 4727-4736.

Krivelyova A. and C. Robotti (2003). Playing the field: Geomagnetic storms and international stock markets. Working Paper No. 2003-5b, Federal Reserve Bank of Atlanta.

Isen A. M. and N. Geva (1987). The influence of positive affect on acceptable level of risk: The person with a large canoe has a large worry, Organizational Behavior and Human Decision Process, 39, pp. $145-154$.

Isen, A. M. and Labroo, A. A. (2003). Some Ways in Which Positive Affect Facilitates Decision Making and Judgment. In: Schneider, Sandra L. and Shanteau, James (eds.). Emerging Perspectives on Judgment and Decision Research. Cambridge University Press.

Johnson C. (2005). 'Fifteen NYSE Traders Indicted', The Washington Post, April 13. 
Johnson E. J. and A. Tversky (1983). Affect, generalization, and the perception of risk, Journal of personality and social psychology, 45 (19), pp. 20-31.

LeDoux, Joseph. 1996. The emotional brain: The mysterious underpinnings of emotional life. New York: Simon \& Schuster.

Levy T. and J. Yagil (2011). Air pollution and stock returns in the US, Journal of Economic Psychology, 32 (3), pp. 374-383.

Limpaphayom P., P. R. Locke, and P. Sarajoti (2007). Gone with the Wind: Chicago's Weather and Futures Trading, Journal of Futures Markets, 16 (1).

Ling L., T. D. Ruddy, M. Dalipaj, M. Szyszkowicz, H. You, R. Poon, A. Wheeler, and R. Dales (2007). Influence of Personal Exposure to Particulate Air Pollution on Cardiovascular Physiology and Biomarkers of Inflammation and Oxidative Stress in Subjects With Diabetes, Journal of Occupational and Environmental Medicine, 49 (3), pp. 258-265.

Loewenstein G. (2000). Emotions in economic theory and economic behavior, American Economic Review, 65 , pp. $426-432$.

Loewenstein G., E. U. Weber, C. K. Hsee, and N. Welch (2001). Risk as feelings, Psychological Bulletin, 127, pp. 267-286.

Lucey B. M. and M. Dowling (2005). The role of feelings in investor decision-making, Journal of Economic Surveys, 19 (2), pp. 211-237.

Lundberg A. (1996). Psychiatric aspects of air pollution, Otolaryngology - Head and Neck Surgery, 114 (2), pp. 227-231.

MacLeod C. and L. Campbell (1992). Memory Accessibility and Probability Judgments: An Experimental Evaluation of the Availability Heuristic, Journal of Personality and Social Psychology, 63 (6), pp. 890-902.

Madhavan A. and S. Smidt (1993). An Analysis of Changes in Specialist Inventories and Quotations, The Journal of Finance, 48 (5), pp. 1595-1628.

Maginn J. L., D. L. Tuttle, D. W. McLeavey, J. E. Pinto (2007). Managing investment portfolios: a dynamic process, Publisher: J. Wiley and Sons.

Mann L. (1992). Stress, affect, and risk taking In J. Frank Yates, ed.: Risk-taking Behavior (Wiley, Chichester).

Mayer J., Gaschke Y., Braverman D. and T. Evans (1992). Mood-congruent judgment is a general effect', Journal of Personality and Social Psychology, 63, pp. 119-132.

Mazur A. (1995). Biosocial models of deviant behavior among male army veterans, Biological Psychology, 41, pp. 271-293. 
McElrea H. and L. Standing (1992). Fast music causes fast drinking, Perceptual and Motor Skills, 75, pp. 362-370.

Milliman R. E. (1982). Using background music to affect the behavior of supermarket shoppers, Journal of Marketing, 46, pp. 86-91.

Mittal V. and W. T. Ross (1998). The impact of positive and negative affect and issue framing on issue interpretation and risk taking. Org. Behav. Hum. Decis. Process, 76 (3), pp. 298-324.

Mossetti S., S. P. Angius, and E. Angelino (2005). Assessing the impact of particulate matter sources in the Milan urban area, International Journal of Environment and Pollution, 24 (1-4), pp. 247-259.

Netter P., Henning J. and I. S. Roed (1996). Serotonin and dopamine as mediators of sensation seeking behavior, Neuropsychobiology, 34, pp. 155-165.

Newey W. (1987). Efficient estimation of limited dependent variable models with endogenous explanatory variables, Journal of Econometrics, 36, pp. 231-250.

North A. C. and D. J. Hargreaves (1996). The effects of music on responses to a dining area, Journal of Environmental Psychology, 16, pp. 55-64.

North A. C. and D. J. Hargreaves (1997). Music and consumer behaviour. In D. J. Hargreaves and A. C. North (Eds.), The socialpsychology of music (pp. 268-289). Oxford, UK: Oxford University Press.

North A. C. and D. J. Hargreaves (1998). The Effect of Music on Atmosphere and Purchase Intentions in a Cafeteria, Journal of Applied Social Psychology, 28 (24), pp. 2254-2273.

Östblom G. and E. Samakovlis (2004). Costs of Climate Policy when Pollution Affects Health and Labour Productivity: A General Equilibrium Analysis Applied to Sweden, Working Paper No. 93, The National Institute of Economic Research, Stockholm.

Pardo A. and E. Valor (2003). Spanish stock returns: where is the weather effect?, European financial management, 19 (1), pp. 117-126.

Pia P. (1997). Il mercato azionario italiano, G. Giappichelli Editore, Torino.

Raff H, Goldmann R. W. and E. P. Kindwall (1985). Adrenocortical function after acute carbon monoxide exposure in humans, Archives of Environmental Health, 40, pp. 88-90.

Rosenblitt J. C., Soler H., Johnson S. E. and D. M. Quadagno (2001). Sensation Seeking and Hormones in Men and Women: Exploring the Link, Hormones and Behavior, 40, pp. 396-402.

Rosenthal E. (2007). 'Made in Italy: fashion, food, Fiat, pollution', International Herald Tribune, June 11.

Sagar A., M Bhattacharya, and V. Joon (2007). A Comparative Study of Air Pollution-Related Morbidity Among Exposed Population of Delhi, Indian Journal of Community Medicine, 32 (4), pp. 268-273.

Saunders E. M. (1993). Stock prices and Wall Street weather, American Economic Review, 83 (5), pp. $1337-1345$. 
Schwartz J. (2000). The distributed lag between air pollution and daily deaths, Epidemiology, 11 (3), pp. 320-326.

Schwarz N. (1990). Feelings as information: Informational and motivational functions of affective states. In E. T. Higgins (ed.), Handbook of Motivation and Cognition, Vol. 2. New York: Guildford Press, pp. $527-561$.

Schwarz N. and G. L. Clore (1983). Mood, misattribution, and judgments of well-being: Informative and directive functions of affective states, Journal of Personality and Social Psychology, 45, pp. 513523.

Shulevitz (1989). 'Pollution: the risks for travelers', The New York Times, August 6.

Sofianos G. and I. M. Werner (2000). The trades of NYSE floor brokers, Journal of Financial Markets, 3, pp. 139-176.

Summers T. A. and P. R. Hebert (2001). Shedding some light on store atmospherics: influence of illumination on consumer behavior, Journal of Business Research, 54 (2), pp. 145-150.

Tomei F., Rosati M. V., Ciarrocca M., Baccolo T. P., Gaballo M., Caciari T. And E. Tomao (2003). Plasma Cortisol Levels and Workers Exposed to Urban Pollutants, Industrial Health, 41, pp. 320-326.

Turley L. W. and R. E. Milliman (2000). Atmospheric Effects on Shopping Behavior: A Review of the Experimental Evidence, Journal of Business Research, 49, pp. 193-211.

Wang S., Mason J., Charney D., Yehuda R., Sherry R. and S. Southwick (1997). Relationships between hormonal profile and novelty seeking in combat-related posttraumatic stress disorder, Biological Psychiatry, 41, pp. 145-151.

White H. (1980). A heteroskedastic-consistent covariance matrix estimator and a direct test of heteroskedasticity, Econometrica, 48, pp. 817-838.

World Health Organization (2005). Air quality guidelines global update 2005, Report on a working group meeting, Bonn, Germany, 18-20 October 2005.

World Health Organization - Regional Office for Europe (2006). Health risks of particulate matter from long-range transboundary air pollution, Joint WHO / Convention Task Force on the Health Aspects of Air Pollution, European Centre for Environment and Health, Bonn Office.

Wright W. F. and G. H. Bower (1992). Mood effects on subjective probability assessment, Organizational Behavior and Human Decision Processes, 52 (2) pp. 183- 318.

Yuan K., L. Zheng, and Q. Zhu (2006). Are investors moonstruck? Lunar phases and stock returns, Journal of Empirical Finance, 13 (1), pp. 1-23.

Zeidner M. and M. Schechter (1988). Psychological responses to air pollution: some personality and demographic correlates, Journal of Environmental Psychology, 8, pp. 191-208.

Zuckerman M. (1979). Sensation Seeking: Beyond the Optimal Level of Arousal. Erlbaum, Hillsdale, NJ. 
Zuidema T. and A. Nentjes (1997). Health Damage of Air Pollution: An Estimate of a Dose-Response Relationship for the Netherlands, Environmental and Resource Economics, 9, pp. 291-308. 


\section{Appendix}

\section{International Air Pollution Data}

International air pollution data have been obtained from a variety of sources and cover unequal time spans. Some descriptive statistics are shown in Table 9. Given the complexity of acquiring air pollution data for a sizable sample of countries, we restricted our attention to particulate matter and nitrogen oxides, which appear to be among the most commonly monitored pollutants. For each stock exchange, the pollution data (where available) have been collected from the nearest monitoring station. More specifically, daily data about particulate matter $\left(\mu \mathrm{g} / \mathrm{m}^{3}\right)$ in New York have been collected from the U.S. Environmental Protection Agency, Air Quality System Office, in Durham, NC. The relevant monitor (geographical coordinates: 40.71163, -74.00514) is located about 0.5 miles from Wall Street. Daily data about $\mathrm{PM}$ and $\mathrm{NO}_{\mathrm{x}}\left(\mu \mathrm{g} / \mathrm{m}^{3}\right)$ in Madrid have been obtained from the Madrid Air Quality Department (Departamento de Calidad del Aire de Madrid) and come from the monitoring station in Calle Almirante, about 0.4 miles from the Madrid Stock Exchange. Daily data about PM and NO $\left(\mu \mathrm{g} / \mathrm{m}^{3}\right)$ in Frankfurt have been collected from the Hesse Regional Authority for the Environment (Hessisches Landesamt für Umwelt und Geologie) in Wiesbaden, Germany. The relevant monitoring station is located in Friedberger-Landstrabe, around 0.6 miles from the Frankfurt Stock Exchange. Daily data about $\mathrm{PM}$ and $\mathrm{NO}_{2}$ (measured as air pollution indices) in Shanghai have been obtained from the Shanghai Environment Monitoring Center, and result from a combination of measures coming from nine monitors spread across the city. Hourly data about $\mathrm{NO}_{2}$ (parts per billion) in Dublin have been collected from the Environmental Protection Agency in Johnstown Castle, Ireland, and come from the monitor located in Rathmines, about 1.6 miles from the Irish Stock Exchange. The original unit of measurement (ppb) has been converted to $\mu \mathrm{g} / \mathrm{m}^{3}$ using the conversion rate provided by EPA Ireland. Daily averages have then been constructed from hourly observations. Hourly data about $\mathrm{PM}$ and $\mathrm{NO}_{\mathrm{x}}\left(\mu \mathrm{g} / \mathrm{m}^{3}\right)$ in Toronto have been collected from the Ontario Ministry of the Environment; the relevant monitor is located in Bay/Wellesley St., approximately 1.2 miles from the stock exchange. Daily averages have then been 
constructed from hourly observations. Daily data about $\mathrm{PM}$ and $\mathrm{NO}_{\mathrm{x}}\left(\mu \mathrm{g} / \mathrm{m}^{3}\right)$ in London have been obtained from the Environmental Research Group at King's College London. PM data come from the monitor located in Sir John Cass school, about 1.1 miles from the London Stock Exchange, whereas $\mathrm{NO}_{\mathrm{x}}$ data come from the monitor in Senator House, around 0.3 miles from the Exchange. Daily data about $\mathrm{PM}$ and $\mathrm{NO}_{2}$ $\left(\mu \mathrm{g} / \mathrm{m}^{3}\right)$ in Paris have been collected from the Paris Region Air Quality Network (AIRPARIF, Surveillance de la Qualité de l'Air en Ile-de-France). The relevant monitor is labeled as "Paris $1^{\text {er }}$ Les Halles" and is located about 0.5 miles from the Paris Bourse. Daily data about PM $\left(\mu \mathrm{g} / \mathrm{m}^{3}\right)$ in Sydney have been obtained from the New South Wales Government, Department of Environment and Climate Change. The relevant monitoring station is labeled as "Rozelle" and is located approximately 2.5 miles from the Australian Securities Exchange.

\section{International Stock Return Data, Exchange Trading Systems, and Control Variables}

Information about the trading systems in place in the sample of stock exchanges under investigation has been collected from the World Federation of Exchanges and from the individual exchanges' official web sites. ${ }^{29}$ Daily closing values of the stock market indices employed in the analysis have been collected from Datastream (in what follows the Datastream codes are shown in parenthesis). Daily log returns have then been computed using said closing values. Some descriptive statistics are reported in Table 10. For the U.S. market, the S\&P500 (S\&PCOMP), NYSE composite (NYSEALL), Dow Jones Industrial Average (DJINDUS), Russell 1000 (FRUSSL1), and S\&P600 Small Cap index (S\&P600I) have been included in the study. Both the New York Stock Exchange and the American Stock Exchange (now part of NYSE Euronext) employ a trading floor over the period under scrutiny. For the Spanish market, which features a trading floor in Madrid, the IBEX 35 index (IBEX35I) and the Spain-Datastream market index (TOTMKES) have been employed. For the German market (trading floor in Frankfurt) the Late index L-

\footnotetext{
${ }^{29}$ http://www.world-exchanges.org/.
} 
DAX (DAXL30X) and the Germany-Datastream market index (TOTMKBD) have been used. The L-DAX is calculated from 5:45 p.m. to 8:00 p.m. and measures the performance of the DAX index based on floor trading at the Frankfurt Stock Exchange after the Xetra electronic trading system closes for the day. ${ }^{30}$ As such, if pollution-induced changes in the mood and/or risk aversion of the floor community have an impact on stock prices, this index represents a good candidate for the purpose of detecting such an effect. For the Shanghai Stock Exchange, which features a trading floor over the period at hand, the SSE 50 index (CHSH50I) and the SSE 180 index (CHSH180) have been employed. For the Irish market (trading floor in Dublin until June 6, 2000) the ISEQ Overall index (ISEQUIT) and Ireland-Datastream market index (TOTMKIR) have been considered. For the Toronto Stock Exchange, which features no trading floor during the period covered by this analysis, the TSX Composite index (TTOCOMP) and the CanadaDatastream market index (TOTMKCN) have been employed. For the London Stock Exchange, which has no trading floor during the era under scrutiny, the FTSE 100 index (FTSE100) and the UK-Datastream market index (TOTMKUK) have been included in the study. For the Paris Bourse (now part of Euronext and featuring a floorless trading system over the period under investigation) the CAC 40 index (FRCAC40) and France-Datastream market index (TOTMKFR) have been employed. Lastly, for the Australian Securities Exchange, which has no trading floor over the period at hand, the ASX All Ordinaries index (AUSTOLD) and the Australia-Datastream market index (TOTMKAU) have been included in the empirical examination.

Daily average temperature data (Fahrenheit degrees) for the cities hosting the stock exchanges in the sample have been collected from the National Climatic Data Center in Asheville, NC. Daily dummy variables taking value 1 if a positive amount of rain has fallen on a given day, and zero otherwise, have been constructed based on data from the same source. The remaining control variables have been constructed using the same methodology discussed in the text.

\footnotetext{
${ }^{30}$ See http://deutsche-boerse.com/.
} 
Table 1

Summary Statistics - Air Pollution and Environmental Factors near the MSE

This table displays a number of summary statistics that describe the Italian data sample. For each variable, summary statistics are reported for two sub-samples, the first one (upper row) covering the period when trading at the MSE was conducted on the floor, and the second one (lower row) referring to the era in which trading was delocalized. All the variables have been measured daily by a monitoring station located near the MSE.

\begin{tabular}{|c|c|c|c|c|c|}
\hline Factor & Sample Period & Mean & Std & Min & Max \\
\hline \multirow{2}{*}{$\mathrm{PM}\left(\mu \mathrm{g} / \mathrm{m}^{3}\right)$} & $\begin{array}{c}01 / 02 / 1989-04 / 14 / 1994 \\
(1595 \text { obs })\end{array}$ & 81.23 & 45.05 & 9 & 399.43 \\
\hline & $\begin{array}{c}04 / 15 / 1994-02 / 13 / 1998 \\
(1339 \text { obs })\end{array}$ & 55.08 & 20.05 & 5.13 & 148.77 \\
\hline \multirow{2}{*}{$\mathrm{NO}_{\mathrm{x}}\left(\mu \mathrm{g} / \mathrm{m}^{3}\right)$} & $\begin{array}{c}01 / 02 / 1989-04 / 14 / 1994 \\
(1654 \text { obs })\end{array}$ & 325.90 & 278.53 & 12.86 & 1974.31 \\
\hline & $\begin{array}{c}04 / 15 / 1994-05 / 19 / 2006 \\
(4295 \mathrm{obs})\end{array}$ & 187.52 & 159.99 & 17.29 & 1501.50 \\
\hline \multirow{2}{*}{$\mathrm{SO} 2\left(\mu \mathrm{g} / \mathrm{m}^{3}\right)$} & $\begin{array}{c}01 / 02 / 1989-04 / 14 / 1994 \\
(878 \text { obs })\end{array}$ & 57.56 & 68.39 & .04 & 419.42 \\
\hline & $\begin{array}{c}04 / 15 / 1994-05 / 19 / 2006 \\
\text { (4182 obs) }\end{array}$ & 16.59 & 17.95 & 0 & 163.36 \\
\hline \multirow{2}{*}{ Temperature $\left(\mathrm{C}^{\circ}\right)$} & $\begin{array}{c}01 / 02 / 1989-04 / 14 / 1994 \\
(1580 \text { obs })\end{array}$ & 13.95 & 7.78 & -4.60 & 29.80 \\
\hline & $\begin{array}{c}04 / 15 / 1994-05 / 19 / 2006 \\
(4336 \text { obs })\end{array}$ & 14.22 & 7.84 & -4.80 & 32.00 \\
\hline \multirow{2}{*}{ Rain (mm) } & $\begin{array}{c}01 / 02 / 1989-04 / 14 / 1994 \\
(1517 \text { obs })\end{array}$ & 2.29 & 7.69 & 0 & 122.20 \\
\hline & $\begin{array}{c}04 / 15 / 1994-05 / 19 / 2006 \\
\text { (4382 obs) }\end{array}$ & 2.51 & 8.05 & 0 & 212 \\
\hline \multirow{2}{*}{ Wind $(\mathrm{m} / \mathrm{s})$} & $\begin{array}{c}01 / 02 / 1989-04 / 14 / 1994 \\
(1440 \text { obs })\end{array}$ & 1.43 & .57 & .39 & 5.49 \\
\hline & $\begin{array}{c}04 / 15 / 1994-05 / 19 / 2006 \\
(4334 \text { obs })\end{array}$ & 1.65 & .61 & .20 & 6.79 \\
\hline \multirow{2}{*}{ Pressure (hPa) } & $\begin{array}{c}01 / 02 / 1989-04 / 14 / 1994 \\
(1581 \text { obs })\end{array}$ & 1005.31 & 8.07 & 977.21 & 1027.28 \\
\hline & $\begin{array}{c}04 / 15 / 1994-05 / 19 / 2006 \\
(4302 \text { obs })\end{array}$ & 1001.53 & 7.36 & 969.59 & 1023.60 \\
\hline
\end{tabular}


Table 2

Summary Statistics - MSE Stock Returns

This table displays a number of summary statistics that describe the time series of Italian stock returns used in the analysis. For each variable, summary statistics are reported for two sub-samples, the first one (upper row) covering the period when trading at the MSE was conducted on the floor, and the second one (lower row) referring to the era in which trading was delocalized. Comit Global, Datastream Italy-market, and MIB Storico are global indices of the Italian stock market. Equity returns are expressed in percentage points.

\begin{tabular}{|c|c|c|c|c|c|c|c|}
\hline Market Index & Sample Period & Mean & Std & Min & Max & Skewness & Kurtosis \\
\hline \multirow{2}{*}{ Comit Global } & $\begin{array}{c}01 / 02 / 1989-04 / 14 / 1994 \\
(1334 \text { obs) }\end{array}$ & .021 & 1.14 & -7.34 & 4.59 & -.41 & 7.24 \\
\hline & $\begin{array}{c}04 / 15 / 1994-05 / 19 / 2006 \\
(3070 \mathrm{obs})\end{array}$ & .026 & 1.19 & -8.47 & 6.22 & -.53 & 6.54 \\
\hline \multirow{2}{*}{$\begin{array}{l}\text { Datastream } \\
\text { Italy-market }\end{array}$} & $\begin{array}{c}01 / 02 / 1989-04 / 14 / 1994 \\
(1334 \text { obs })\end{array}$ & .019 & 1.17 & -7.59 & 5.26 & -.34 & 7.02 \\
\hline & $\begin{array}{c}04 / 15 / 1994-05 / 19 / 2006 \\
(3070 \mathrm{obs})\end{array}$ & .024 & 1.27 & -7.79 & 6.90 & -.18 & 5.94 \\
\hline \multirow{2}{*}{ MIB Storico } & $\begin{array}{c}\text { 01/03/1989-04/14/1994 } \\
\text { (1334 obs) }\end{array}$ & .021 & 1.16 & -7.55 & 4.74 & -.40 & 7.36 \\
\hline & $\begin{array}{c}04 / 15 / 1994-05 / 19 / 2006 \\
(3070 \text { obs })\end{array}$ & .026 & 1.19 & -8.48 & 6.22 & -.54 & 6.58 \\
\hline
\end{tabular}


Table 3

Air Pollution and Stock Returns - A Natural Experiment

This table displays the results of estimating logit model [1]. The left-hand side of the table contains the coefficient estimates produced using the first sub-sample of data, covering the period when trading at the MSE was conducted on the floor. The right-hand side shows the estimates generated using the second sub-sample, which refers to the era in which trading was delocalized. The dependent variable is the probability that returns will be positive on day $t$. The air pollution proxy employed as an explanatory variable is the level of particulate matter (PM) recorded near the MSE on day $t-1$. The coefficient on said variable measures the marginal effect of a $10 \mu \mathrm{g} / \mathrm{m}^{3}$ increase in particulate matter. All the other coefficients measure the marginal effect of the corresponding explanatory variable on the dependent variable. Robust standard errors are in parenthesis below the corresponding coefficients. One, two, and three asterisks denote statistical significance at the ten, five, and one percent level, respectively.

\begin{tabular}{|c|c|c|c|c|c|c|}
\hline & \multicolumn{3}{|c|}{ Centralized Market } & \multicolumn{3}{|c|}{ Decentralized Market } \\
\hline & $\begin{array}{c}\text { Comit } \\
\text { Global } \\
01 / 02 / 1989- \\
04 / 14 / 1994 \\
\end{array}$ & $\begin{array}{c}\text { Datastream } \\
\text { Italy-market } \\
01 / 02 / 1989- \\
04 / 14 / 1994 \\
\end{array}$ & $\begin{array}{c}\text { MIB } \\
\text { Storico } \\
01 / 02 / 1989- \\
04 / 14 / 1994 \\
\end{array}$ & $\begin{array}{c}\text { Comit } \\
\text { Global } \\
04 / 15 / 1994- \\
02 / 13 / 1998\end{array}$ & $\begin{array}{c}\text { Datastream } \\
\text { Italy-market } \\
04 / 15 / 1994- \\
02 / 13 / 1998 \\
\end{array}$ & $\begin{array}{c}\text { MIB } \\
\text { Storico } \\
04 / 15 / 1994- \\
02 / 13 / 1998 \\
\end{array}$ \\
\hline$\mu_{P M_{t-1}}$ & $\begin{array}{c}-.0149 * * * \\
(.0042)\end{array}$ & $\begin{array}{c}-.0164 * * * \\
(.0043)\end{array}$ & $\begin{array}{c}-.0151^{* * *} \\
(.0043)\end{array}$ & $\begin{array}{c}.0115 \\
(.0095)\end{array}$ & $\begin{array}{c}.0065 \\
(.0095)\end{array}$ & $\begin{array}{c}.0122 \\
(.0095)\end{array}$ \\
\hline$\gamma_{S A D}$ & $\begin{array}{c}.094 \\
(.075)\end{array}$ & $\begin{array}{c}.071 \\
(.074)\end{array}$ & $\begin{array}{l}.120 \\
(.076)\end{array}$ & $\begin{array}{c}.049 \\
(.078)\end{array}$ & $\begin{array}{l}.113 \\
(.079)\end{array}$ & $\begin{array}{c}.046 \\
(.078)\end{array}$ \\
\hline$\gamma_{\text {Fall }}$ & $\begin{array}{l}-.074 \\
(.097)\end{array}$ & $\begin{array}{l}-.138 \\
(.098)\end{array}$ & $\begin{array}{l}-.055 \\
(.098)\end{array}$ & $\begin{array}{l}-.120 \\
(.093)\end{array}$ & $\begin{array}{c}-.192 * * \\
(.089)\end{array}$ & $\begin{array}{l}-.120 \\
(.093)\end{array}$ \\
\hline$\gamma_{\text {FullMoon }}$ & $\begin{array}{l}-.067 \\
(.044)\end{array}$ & $\begin{array}{l}-.081 * \\
(.042)\end{array}$ & $\begin{array}{l}-.063 \\
(.044)\end{array}$ & $\begin{array}{c}.064 \\
(.041)\end{array}$ & $\begin{array}{l}.093 * * \\
(.041)\end{array}$ & $\begin{array}{c}.066 \\
(.041)\end{array}$ \\
\hline$\gamma_{\text {NewMoon }}$ & $\begin{array}{l}-.046 \\
(.043)\end{array}$ & $\begin{array}{c}-.104 * * \\
(.043)\end{array}$ & $\begin{array}{l}-.044 \\
(.043)\end{array}$ & $\begin{array}{l}.030 \\
(.041)\end{array}$ & $\begin{array}{c}.024 \\
(.042)\end{array}$ & $\begin{array}{c}.032 \\
(.041)\end{array}$ \\
\hline$\gamma_{\text {Monday }}$ & $\begin{array}{c}-.119 * * * \\
(.042)\end{array}$ & $\begin{array}{c}-.089 * * \\
(.043)\end{array}$ & $\begin{array}{c}-.133 * * * \\
(.042)\end{array}$ & $\begin{array}{c}-.089 * * \\
(.043)\end{array}$ & $\begin{array}{c}-.103 * * \\
(.043)\end{array}$ & $\begin{array}{c}-.087 * * \\
(.043)\end{array}$ \\
\hline$\gamma_{\operatorname{Tax}}$ & $\begin{array}{l}-.043 \\
(.173)\end{array}$ & $\begin{array}{c}.053 \\
(.178)\end{array}$ & $\begin{array}{l}-.054 \\
(.173)\end{array}$ & $\begin{array}{l}.257 * * \\
(.126)\end{array}$ & $\begin{array}{l}-.053 \\
(.161)\end{array}$ & $\begin{array}{l}.259 * * \\
(.126)\end{array}$ \\
\hline$\gamma_{\text {Temp }}$ & $\begin{array}{c}.010 \\
(.007)\end{array}$ & $\begin{array}{c}.005 \\
(.007)\end{array}$ & $\begin{array}{l}.012 * \\
(.007)\end{array}$ & $\begin{array}{l}-.005 \\
(.007)\end{array}$ & $\begin{array}{l}-.003 \\
(.007)\end{array}$ & $\begin{array}{l}-.005 \\
(.007)\end{array}$ \\
\hline$\gamma_{\text {Rain }}$ & $\begin{array}{c}.015 \\
(.041)\end{array}$ & $\begin{array}{l}-.029 \\
(.040)\end{array}$ & $\begin{array}{c}.023 \\
(.041)\end{array}$ & $\begin{array}{l}-.030 \\
(.040)\end{array}$ & $\begin{array}{l}-.042 \\
(.039)\end{array}$ & $\begin{array}{l}-.029 \\
(.040)\end{array}$ \\
\hline Pseudo $R^{2}$ & 0.047 & 0.037 & 0.047 & 0.031 & 0.029 & 0.032 \\
\hline Obs & 877 & 877 & 877 & 915 & 915 & 915 \\
\hline
\end{tabular}


Table 4

Air Pollution and Stock Returns - Three-Day Air Pollution Moving Average

This table displays the results of estimating logit model [1] when the one-day lagged pollution variable is replaced by the three-day air pollution moving average defined in formula [3]. The coefficient on the latter variable measures the marginal effect of a $10 \mu \mathrm{g} / \mathrm{m}^{3}$ increase in the average level of particulate matter between day $t-3$ and day $t-1$. All the other coefficients measure the marginal effect of the corresponding explanatory variable on the dependent variable. The dependent variable is the probability that returns will be positive on day $t$. The left-hand side of the table contains the coefficient estimates produced using the first sub-sample of data, covering the period when trading at the MSE was conducted on the floor. The right-hand side shows the estimates generated using the second sub-sample, which refers to the era in which trading was delocalized. Robust standard errors are in parenthesis below the corresponding coefficients. One, two, and three asterisks denote statistical significance at the ten, five, and one percent level, respectively.

\begin{tabular}{|c|c|c|c|c|c|c|}
\hline & \multicolumn{3}{|c|}{ Centralized Market } & \multicolumn{3}{|c|}{ Decentralized Market } \\
\hline & $\begin{array}{l}\text { Comit } \\
\text { Global } \\
01 / 02 / 1989- \\
04 / 14 / 1994 \\
\end{array}$ & $\begin{array}{c}\text { Datastream } \\
\text { Italy-market } \\
01 / 02 / 1989- \\
04 / 14 / 1994\end{array}$ & $\begin{array}{c}\text { MIB } \\
\text { Storico } \\
01 / 02 / 1989- \\
04 / 14 / 1994 \\
\end{array}$ & $\begin{array}{c}\text { Comit } \\
\text { Global } \\
04 / 15 / 1994- \\
02 / 13 / 1998\end{array}$ & $\begin{array}{c}\text { Datastream } \\
\text { Italy-market } \\
04 / 15 / 1994- \\
02 / 13 / 1998 \\
\end{array}$ & $\begin{array}{c}\text { MIB } \\
\text { Storico } \\
04 / 15 / 1994- \\
02 / 13 / 1998 \\
\end{array}$ \\
\hline$\mu_{P M}^{\text {Average }}$ & $\begin{array}{c}-.0194 * * * \\
(.0054)\end{array}$ & $\begin{array}{c}-.0200 * * * \\
(.0054)\end{array}$ & $\begin{array}{c}-.0196^{* * *} \\
(.0054)\end{array}$ & $\begin{array}{c}.0162 \\
(.0113)\end{array}$ & $\begin{array}{c}.0137 \\
(.0114)\end{array}$ & $\begin{array}{c}.0166 \\
(.0114)\end{array}$ \\
\hline$\gamma_{S A D}$ & $\begin{array}{l}.119 \\
(.082)\end{array}$ & $\begin{array}{l}.085 \\
(.080)\end{array}$ & $\begin{array}{l}.152 * \\
(.082)\end{array}$ & $\begin{array}{l}.027 \\
(.079)\end{array}$ & $\begin{array}{c}.118 \\
(.08071)\end{array}$ & $\begin{array}{l}.024 \\
(.079)\end{array}$ \\
\hline$\gamma_{\text {Fall }}$ & $\begin{array}{l}-.078 \\
(.098)\end{array}$ & $\begin{array}{l}-.139 \\
(.094)\end{array}$ & $\begin{array}{l}-.058 \\
(.098)\end{array}$ & $\begin{array}{l}-.168^{*} \\
(.098)\end{array}$ & $\begin{array}{c}-.205 * * \\
(.092)\end{array}$ & $\begin{array}{l}-.167 * \\
(.098)\end{array}$ \\
\hline$\gamma_{\text {FullMoon }}$ & $\begin{array}{l}-.081 * \\
(.046)\end{array}$ & $\begin{array}{c}-.088 * * \\
(.044)\end{array}$ & $\begin{array}{l}-.070 \\
(.045)\end{array}$ & $\begin{array}{l}.071 * \\
(.042)\end{array}$ & $\begin{array}{l}.088 * * \\
(.042)\end{array}$ & $\begin{array}{l}.073^{*} \\
(.042)\end{array}$ \\
\hline$\gamma_{\text {NewMoon }}$ & $\begin{array}{l}-.030 \\
(.045)\end{array}$ & $\begin{array}{c}-.092 * * \\
(.046)\end{array}$ & $\begin{array}{l}-.029 \\
(.045)\end{array}$ & $\begin{array}{l}.023 \\
(.043)\end{array}$ & $\begin{array}{l}.016 \\
(.043)\end{array}$ & $\begin{array}{l}.025 \\
(.043)\end{array}$ \\
\hline$\gamma_{\text {Monday }}$ & $\begin{array}{c}-.133 * * * \\
(.043)\end{array}$ & $\begin{array}{l}-.078^{*} \\
(.044)\end{array}$ & $\begin{array}{c}-.139 * * * \\
(.043)\end{array}$ & $\begin{array}{c}-.086 * * \\
(.043)\end{array}$ & $\begin{array}{c}-.108 * * \\
(.043)\end{array}$ & $\begin{array}{l}-.084 * \\
(.043)\end{array}$ \\
\hline$\gamma_{\operatorname{Tax}}$ & $\begin{array}{l}-.028 \\
(.175)\end{array}$ & $\begin{array}{l}.076 \\
(.177)\end{array}$ & $\begin{array}{l}-.041 \\
(.175)\end{array}$ & $\begin{array}{l}.271 * * \\
(.122)\end{array}$ & $\begin{array}{l}-.044 \\
(.164)\end{array}$ & $\begin{array}{l}.272 * * \\
(.122)\end{array}$ \\
\hline$\gamma_{\text {Temp }}$ & $\begin{array}{c}.009 \\
(.007)\end{array}$ & $\begin{array}{l}.004 \\
(.007)\end{array}$ & $\begin{array}{l}.011 \\
(.007)\end{array}$ & $\begin{array}{l}-.007 \\
(.007)\end{array}$ & $\begin{array}{l}-.004 \\
(.007)\end{array}$ & $\begin{array}{l}-.007 \\
(.007)\end{array}$ \\
\hline$\gamma_{\text {Rain }}$ & $\begin{array}{l}.018 \\
(.043)\end{array}$ & $\begin{array}{l}-.020 \\
(.042)\end{array}$ & $\begin{array}{l}.026 \\
(.043)\end{array}$ & $\begin{array}{l}-.045 \\
(.041)\end{array}$ & $\begin{array}{l}-.032 \\
(.041)\end{array}$ & $\begin{array}{l}-.043 \\
(.041)\end{array}$ \\
\hline Pseudo $R^{2}$ & 0.051 & 0.039 & 0.049 & 0.036 & 0.031 & 0.036 \\
\hline Obs & 796 & 796 & 796 & 875 & 875 & 875 \\
\hline
\end{tabular}


Table 5

Instrumental Variables Estimation - Linear Probability Model

This table reports the coefficients from the IV estimation presented in model [5] and [6]. The instruments are wind speed and atmospheric pressure, both employed with a lag, as specified in section 6.4. The left-hand side of the table contains the coefficient estimates produced using the first sub-sample of data, covering the period when trading at the MSE was conducted on the floor. The right-hand side shows the estimates generated using the second sub-sample, which refers to the era in which trading was delocalized. The dependent variable is the probability that returns will be positive on day $t$. The air pollution proxy employed as an explanatory variable is the level of particulate matter (PM) recorded near the MSE on day $t-1$. The coefficient on such a variable measures the marginal effect of a $10 \mu \mathrm{g} / \mathrm{m}^{3}$ increase in particulate matter. All the other coefficients measure the marginal effect of the corresponding explanatory variables on the dependent variable. Robust standard errors are in parenthesis below the corresponding coefficients. One, two, and three asterisks denote statistical significance at the ten, five, and one percent level, respectively.

\begin{tabular}{|c|c|c|c|c|c|c|}
\hline & \multicolumn{3}{|c|}{ Centralized Market } & \multicolumn{3}{|c|}{ Decentralized Market } \\
\hline & $\begin{array}{c}\text { Comit } \\
\text { Global } \\
01 / 02 / 1989- \\
04 / 14 / 1994 \\
\end{array}$ & $\begin{array}{c}\text { Datastream } \\
\text { Italy-market } \\
01 / 02 / 1989- \\
04 / 14 / 1994 \\
\end{array}$ & $\begin{array}{c}\text { MIB } \\
\text { Storico } \\
01 / 02 / 1989- \\
04 / 14 / 1994 \\
\end{array}$ & $\begin{array}{c}\text { Comit } \\
\text { Global } \\
04 / 15 / 1994- \\
02 / 13 / 1998 \\
\end{array}$ & $\begin{array}{c}\text { Datastream } \\
\text { Italy-market } \\
04 / 15 / 1994- \\
02 / 13 / 1998 \\
\end{array}$ & $\begin{array}{c}\text { MIB } \\
\text { Storico } \\
04 / 15 / 1994- \\
02 / 13 / 1998 \\
\end{array}$ \\
\hline$\mu_{P M_{t-1}}$ & $\begin{array}{l}-.0169 * \\
(.0099)\end{array}$ & $\begin{array}{l}-.0164 * \\
(.0098)\end{array}$ & $\begin{array}{l}-.0133 \\
(.0098)\end{array}$ & $\begin{array}{l}-.0372 \\
(.0299)\end{array}$ & $\begin{array}{l}-.0289 \\
(.0296)\end{array}$ & $\begin{array}{l}-.0379 \\
(.0030)\end{array}$ \\
\hline$\gamma_{S A D}$ & $\begin{array}{l}.104 \\
(.077)\end{array}$ & $\begin{array}{c}.078 \\
(.077)\end{array}$ & $\begin{array}{l}.124 \\
(.077)\end{array}$ & $\begin{array}{c}.091 \\
(.084)\end{array}$ & $\begin{array}{l}.151 * \\
(.082)\end{array}$ & $\begin{array}{c}.089 \\
(.084)\end{array}$ \\
\hline$\gamma_{\text {Fall }}$ & $\begin{array}{l}-.056 \\
(.102)\end{array}$ & $\begin{array}{l}-.109 \\
(.101)\end{array}$ & $\begin{array}{l}-.065 \\
(.103)\end{array}$ & $\begin{array}{l}-.078 \\
(.084)\end{array}$ & $\begin{array}{l}-.157^{*} \\
(.084)\end{array}$ & $\begin{array}{l}-.077 \\
(.084)\end{array}$ \\
\hline$\gamma_{\text {FullMoon }}$ & $\begin{array}{l}-.053 \\
(.045)\end{array}$ & $\begin{array}{l}-.063 \\
(.044)\end{array}$ & $\begin{array}{l}-.050 \\
(.045)\end{array}$ & $\begin{array}{c}.050 \\
(.043)\end{array}$ & $\begin{array}{l}.076 * \\
(.042)\end{array}$ & $\begin{array}{c}.052 \\
(.043)\end{array}$ \\
\hline$\gamma_{\text {NewMoon }}$ & $\begin{array}{l}-.031 \\
(.044)\end{array}$ & $\begin{array}{l}-.060 \\
(.045)\end{array}$ & $\begin{array}{l}-.031 \\
(.044)\end{array}$ & $\begin{array}{c}.045 \\
(.042)\end{array}$ & $\begin{array}{c}.033 \\
(.043)\end{array}$ & $\begin{array}{c}.047 \\
(.042)\end{array}$ \\
\hline$\gamma_{\text {Monday }}$ & $\begin{array}{c}-.120 * * * \\
(.047)\end{array}$ & $\begin{array}{l}-.087 * \\
(.047)\end{array}$ & $\begin{array}{c}-.122 * * * \\
(.047)\end{array}$ & $\begin{array}{c}-.109 * * \\
(.045)\end{array}$ & $\begin{array}{c}-.127 * * * \\
(.045)\end{array}$ & $\begin{array}{c}-.108 * * \\
(.045)\end{array}$ \\
\hline$\gamma_{\operatorname{Tax}}$ & $\begin{array}{l}-.236 \\
(.191)\end{array}$ & $\begin{array}{l}-.113 \\
(.194)\end{array}$ & $\begin{array}{l}-.236 \\
(.188)\end{array}$ & $\begin{array}{l}.186 \\
(.139)\end{array}$ & $\begin{array}{l}-.106 \\
(.149)\end{array}$ & $\begin{array}{l}.185 \\
(.139)\end{array}$ \\
\hline$\gamma_{\text {Temp }}$ & $\begin{array}{l}.0129 * \\
(.007)\end{array}$ & $\begin{array}{c}.008 \\
(.007)\end{array}$ & $\begin{array}{l}.013 * \\
(.007)\end{array}$ & $\begin{array}{c}.002 \\
(.008)\end{array}$ & $\begin{array}{c}.001 \\
(.008)\end{array}$ & $\begin{array}{c}.002 \\
(.008)\end{array}$ \\
\hline$\gamma_{\text {Rain }}$ & $\begin{array}{c}.044 \\
(.042)\end{array}$ & $\begin{array}{l}-.007 \\
(.042)\end{array}$ & $\begin{array}{c}.049 \\
(.042)\end{array}$ & $\begin{array}{l}-.018 \\
(.040)\end{array}$ & $\begin{array}{l}-.029 \\
(.039)\end{array}$ & $\begin{array}{l}-.017 \\
(.040)\end{array}$ \\
\hline Obs & 793 & 793 & 793 & 889 & 889 & 889 \\
\hline
\end{tabular}


Table 6

Instrumental Variables Estimation - Three-Day Air Pollution Moving Average

This table reports the coefficients from the IV estimation presented in model [5] and [6] in which the one-day lagged pollution variable has been replaced by the three-day air pollution moving average defined in formula [3]. The coefficient on the latter variable measures the marginal effect of a $10 \mu \mathrm{g} / \mathrm{m}^{3}$ increase in the average level of particulate matter between day $t-3$ and day $t-1$. The dependent variable is the probability that returns will be positive on day $t$. The instruments are wind speed and atmospheric pressure, both employed with a lag, as specified in section 6.4. The left-hand side of the table contains the coefficient estimates produced using the first sub-sample of data, covering the period when trading at the MSE was conducted on the floor. The right-hand side shows the estimates generated using the second sub-sample, which refers to the era in which trading was delocalized. Robust standard errors are in parenthesis below the corresponding coefficients. One, two, and three asterisks denote statistical significance at the ten, five, and one percent level, respectively. The remaining coefficients are not reported due to space limitations.

\begin{tabular}{|c|c|c|c|c|c|c|}
\hline & \multicolumn{3}{|c|}{ Centralized Market } & \multicolumn{3}{|c|}{ Decentralized Market } \\
\hline & $\begin{array}{c}\text { Comit } \\
\text { Global } \\
01 / 02 / 1989- \\
04 / 14 / 1994 \\
\end{array}$ & $\begin{array}{c}\text { Datastream } \\
\text { Italy-market } \\
01 / 02 / 1989- \\
04 / 14 / 1994 \\
\end{array}$ & $\begin{array}{c}\text { MIB } \\
\text { Storico } \\
01 / 02 / 1989- \\
04 / 14 / 1994 \\
\end{array}$ & $\begin{array}{c}\text { Comit } \\
\text { Global } \\
04 / 15 / 1994- \\
02 / 13 / 1998 \\
\end{array}$ & $\begin{array}{c}\text { Datastream } \\
\text { Italy-market } \\
04 / 15 / 1994- \\
02 / 13 / 1998 \\
\end{array}$ & $\begin{array}{c}\text { MIB } \\
\text { Storico } \\
04 / 15 / 1994- \\
02 / 13 / 1998 \\
\end{array}$ \\
\hline \multicolumn{7}{|c|}{ Marginal effect of PM (three-day moving average, from $t-3$ to $t-1$ ) } \\
\hline$\mu_{P M}^{\text {Average }}$ & $\begin{array}{l}-.0195^{*} \\
(.0116)\end{array}$ & $\begin{array}{l}-.0212 * \\
(.0117)\end{array}$ & $\begin{array}{c}-.0179 \\
(.0116)\end{array}$ & $\begin{array}{c}-.0233 \\
(.0367)\end{array}$ & $\begin{array}{c}-.0228 \\
(.0363)\end{array}$ & $\begin{array}{c}-.0241 \\
(.0367)\end{array}$ \\
\hline Obs & 726 & 726 & 726 & 856 & 856 & 856 \\
\hline
\end{tabular}


Table 7

Instrumental Variables Estimation - Alternative Pollution Proxy: NO $_{\mathrm{x}}$

This table reports the coefficients from the IV estimation presented in model [5] and [6] in which $\mathrm{NO}_{\mathrm{x}}$ replaces particulate matter as the air pollution proxy. The instruments are wind speed and atmospheric pressure, both employed with a lag, as specified in section 6.4. The left-hand side of the table contains the coefficient estimates produced using the first sub-sample of data, covering the period when trading at the MSE was conducted on the floor. The right-hand side shows the estimates generated using the second sub-sample, which refers to the era in which trading was delocalized. The dependent variable is the probability that returns will be positive on day $t$. The air pollution proxy employed as an explanatory variable is the level of $\mathrm{NO}_{\mathrm{x}}$ recorded near the MSE. The coefficient on such a variable measures the marginal effect of a $10 \mu \mathrm{g} / \mathrm{m}^{3}$ increase in $\mathrm{NO}_{\mathrm{x}}$ on day $t-1$ (Panel A), or a $10 \mu \mathrm{g} / \mathrm{m}^{3}$ increase in the average level of $\mathrm{NO}_{\mathrm{x}}$ between day $t-3$ and $t-1$ (Panel B). Robust standard errors are in parenthesis below the corresponding coefficients. One, two, and three asterisks denote statistical significance at the ten, five, and one percent level, respectively. The remaining coefficients are not reported due to space limitations.

\begin{tabular}{|c|c|c|c|c|c|c|}
\hline & \multicolumn{3}{|c|}{ Centralized Market } & \multicolumn{3}{|c|}{ Decentralized Market } \\
\hline & $\begin{array}{c}\text { Comit } \\
\text { Global } \\
01 / 02 / 1989- \\
04 / 14 / 1994 \\
\end{array}$ & $\begin{array}{c}\text { Datastream } \\
\text { Italy-market } \\
01 / 02 / 1989- \\
04 / 14 / 1994 \\
\end{array}$ & $\begin{array}{c}\text { MIB } \\
\text { Storico } \\
01 / 02 / 1989- \\
04 / 14 / 1994 \\
\end{array}$ & $\begin{array}{c}\text { Comit } \\
\text { Global } \\
04 / 15 / 1994- \\
05 / 19 / 2006 \\
\end{array}$ & $\begin{array}{c}\text { Datastream } \\
\text { Italy-market } \\
04 / 15 / 1994- \\
05 / 19 / 2006 \\
\end{array}$ & $\begin{array}{c}\text { MIB } \\
\text { Storico } \\
04 / 15 / 1994- \\
05 / 19 / 2006 \\
\end{array}$ \\
\hline \multicolumn{7}{|c|}{ Panel A: marginal effect of $\mathrm{NO}_{x}(1-$ day lag) } \\
\hline$\mu_{N O x_{t-1}}$ & $\begin{array}{l}-.0042 \\
(.0032)\end{array}$ & $\begin{array}{l}-.0029 \\
(.0033)\end{array}$ & $\begin{array}{l}-.0036 \\
(.0033)\end{array}$ & $\begin{array}{l}-.0018 \\
(.0034)\end{array}$ & $\begin{array}{l}-.0017 \\
(.0034)\end{array}$ & $\begin{array}{l}-.0014 \\
(.0034)\end{array}$ \\
\hline Obs & 820 & 820 & 820 & 2809 & 2809 & 2809 \\
\hline \multicolumn{7}{|c|}{ Panel B: marginal effect of $N O_{x}$ (three-day moving average, from $t$-3 to $\left.t-1\right)$} \\
\hline$\mu_{N O x}^{\text {Average }}$ & $\begin{array}{c}-.0057 * * \\
(.0030)\end{array}$ & $\begin{array}{c}-.0059 * * \\
(.0030)\end{array}$ & $\begin{array}{l}-.0052 * \\
(.0030)\end{array}$ & $\begin{array}{c}.0009 \\
(.0031)\end{array}$ & $\begin{array}{c}-.0004 \\
(.0031)\end{array}$ & $\begin{array}{c}.0012 \\
(.0031)\end{array}$ \\
\hline Obs & 791 & 791 & 791 & 2757 & 2757 & 2757 \\
\hline
\end{tabular}


Table 8

Instrumental Variables Estimation - Alternative Pollution Proxy: $\mathrm{SO}_{2}$

This table reports the coefficients from the IV estimation presented in model [5] and [6] in which $\mathrm{SO}_{2}$ replaces particulate matter as the air pollution proxy. The instruments are wind speed and atmospheric pressure, both employed with a lag, as specified in section 6.4. The left-hand side of the table contains the coefficient estimates produced using the first sub-sample of data, covering the period when trading at the MSE was conducted on the floor. The right-hand side shows the estimates generated using the second sub-sample, which refers to the era in which trading was delocalized. The dependent variable is the probability that returns will be positive on day $t$. The air pollution proxy employed as an explanatory variable is the level of $\mathrm{SO}_{2}$ recorded near the MSE. The coefficient on such a variable measures the marginal effect of a $10 \mu \mathrm{g} / \mathrm{m}^{3}$ increase in $\mathrm{SO}_{2}$ on day $t-1$ (Panel A), or a $10 \mu \mathrm{g} / \mathrm{m}^{3}$ increase in the average level of $\mathrm{SO}_{2}$ between day $t-3$ and $t-1$ (Panel B). Robust standard errors are in parenthesis below the corresponding coefficients. One, two, and three asterisks denote statistical significance at the ten, five, and one percent level, respectively. The remaining coefficients are not reported due to space limitations.

\begin{tabular}{|c|c|c|c|c|c|c|}
\hline & \multicolumn{3}{|c|}{ Centralized Market } & \multicolumn{3}{|c|}{ Decentralized Market } \\
\hline & $\begin{array}{c}\text { Comit } \\
\text { Global } \\
01 / 02 / 1989- \\
04 / 14 / 1994 \\
\end{array}$ & $\begin{array}{c}\text { Datastream } \\
\text { Italy-market } \\
01 / 02 / 1989- \\
04 / 14 / 1994\end{array}$ & $\begin{array}{c}\text { MIB } \\
\text { Storico } \\
01 / 02 / 1989- \\
04 / 14 / 1994 \\
\end{array}$ & $\begin{array}{c}\text { Comit } \\
\text { Global } \\
04 / 15 / 1994- \\
05 / 19 / 2006\end{array}$ & $\begin{array}{c}\text { Datastream } \\
\text { Italy-market } \\
04 / 15 / 1994- \\
05 / 19 / 2006\end{array}$ & $\begin{array}{c}\text { MIB } \\
\text { Storico } \\
04 / 15 / 1994- \\
05 / 19 / 2006 \\
\end{array}$ \\
\hline \multicolumn{7}{|c|}{ Panel A: marginal effect of $\mathrm{SO}_{2}(1-$ day lag) } \\
\hline$\mu_{\mathrm{SO} 2_{t-1}}$ & $\begin{array}{l}-.0195 \\
(.0210)\end{array}$ & $\begin{array}{c}-.0223 \\
(.0217)\end{array}$ & $\begin{array}{c}-.0129 \\
(.0214)\end{array}$ & $\begin{array}{l}-.0291 \\
(.0483)\end{array}$ & $\begin{array}{l}-.0506 \\
(.0500)\end{array}$ & $\begin{array}{l}-.0260 \\
(.0486)\end{array}$ \\
\hline Obs & 404 & 404 & 404 & 2738 & 2738 & 2738 \\
\hline \multicolumn{7}{|c|}{ Panel B: marginal effect of $\mathrm{SO}_{2}$ (three-day moving average, from $t-3$ to $t$-1) } \\
\hline$\mu_{S O 2}^{\text {Average }}$ & $\begin{array}{l}-.0165 \\
(.0215)\end{array}$ & $\begin{array}{c}-.0293 \\
(.0227)\end{array}$ & $\begin{array}{l}-.0091 \\
(.0215)\end{array}$ & $\begin{array}{l}-.0150 \\
(.0469)\end{array}$ & $\begin{array}{l}-.0229 \\
(.0469)\end{array}$ & $\begin{array}{l}-.0123 \\
(.0469)\end{array}$ \\
\hline Obs & 392 & 392 & 392 & 2652 & 2652 & 2652 \\
\hline
\end{tabular}


Table 9

Summary Statistics - International Air Pollution Data

This table displays a number of summary statistics that describe the sample of international air pollution data. Air pollution concentrations are measured in $\mu \mathrm{g} / \mathrm{m}^{3}$ and are taken from monitoring stations that are as close as possible to the corresponding stock exchanges, as described in the appendix.

\begin{tabular}{|c|c|c|c|c|c|c|c|}
\hline City & Pollutant & Sample Period & Mean & Std & Min & Max & Obs. \\
\hline $\begin{array}{l}\text { New York } \\
\text { (Unites States) }\end{array}$ & $\mathrm{PM}_{2.5}$ & $09 / 25 / 2001-12 / 31 / 2008$ & 14.42 & 8.16 & 3.3 & 87.85 & 2565 \\
\hline $\begin{array}{l}\text { Madrid } \\
\text { (Spain) }\end{array}$ & $\begin{array}{l}\mathrm{PM}_{10} \\
\mathrm{NO}_{\mathrm{x}}\end{array}$ & $\begin{array}{l}1 / 7 / 1987-12 / 31 / 2008 \\
1 / 2 / 1990-12 / 31 / 2008\end{array}$ & $\begin{array}{c}39.94 \\
213.90\end{array}$ & $\begin{array}{c}21.46 \\
111.60\end{array}$ & $\begin{array}{c}2 \\
40.49\end{array}$ & $\begin{array}{c}189 \\
1105\end{array}$ & $\begin{array}{l}7662 \\
6739\end{array}$ \\
\hline $\begin{array}{l}\text { Frankfurt } \\
\text { (Germany) }\end{array}$ & $\begin{array}{l}\mathrm{PM}_{10} \\
\mathrm{NO}\end{array}$ & $\begin{array}{c}2 / 21 / 2001-12 / 31 / 2008 \\
1 / 1 / 1998-12 / 31 / 2008\end{array}$ & $\begin{array}{l}34.25 \\
66.68\end{array}$ & $\begin{array}{l}19.21 \\
51.59\end{array}$ & $\begin{array}{c}5.9 \\
3\end{array}$ & $\begin{array}{l}167.9 \\
489.4\end{array}$ & $\begin{array}{l}2796 \\
3957\end{array}$ \\
\hline $\begin{array}{l}\text { Shanghai } \\
\text { (China) }\end{array}$ & $\begin{array}{l}\mathrm{PM}_{10} \\
\mathrm{NO}_{2}\end{array}$ & $\begin{array}{l}7 / 1 / 2002-12 / 31 / 2008 \\
7 / 1 / 2002-12 / 31 / 2008\end{array}$ & $\begin{array}{l}69.58 \\
37.99\end{array}$ & $\begin{array}{l}30.87 \\
18.28\end{array}$ & $\begin{array}{c}12 \\
7\end{array}$ & $\begin{array}{l}500 \\
160\end{array}$ & $\begin{array}{l}2376 \\
2376\end{array}$ \\
\hline $\begin{array}{l}\text { Dublin } \\
\text { (Ireland) }\end{array}$ & $\mathrm{NO}_{2}$ & $1 / 1 / 1988-12 / 31 / 2007$ & 34.93 & 41.11 & 0 & 941.7 & 6039 \\
\hline $\begin{array}{l}\text { Toronto } \\
\text { (Canada) }\end{array}$ & $\mathrm{PM}_{2.5}$ & $1 / 1 / 2003-12 / 31 / 2007$ & 7.69 & 7.02 & 0 & 48.33 & 1826 \\
\hline $\begin{array}{l}\text { London } \\
\text { (UK) }\end{array}$ & $\begin{array}{l}\mathrm{PM}_{10} \\
\mathrm{NO}_{\mathrm{x}}\end{array}$ & $\begin{array}{c}6 / 3 / 2003-12 / 17 / 2008 \\
10 / 11 / 2001-12 / 31 / 2008\end{array}$ & $\begin{array}{l}27.88 \\
88.52\end{array}$ & $\begin{array}{l}12.29 \\
53.91\end{array}$ & $\begin{array}{c}7.2 \\
16.2\end{array}$ & $\begin{array}{c}96 \\
580.1\end{array}$ & $\begin{array}{l}1305 \\
2411\end{array}$ \\
\hline $\begin{array}{l}\text { Paris } \\
\text { (France) }\end{array}$ & $\begin{array}{l}\mathrm{PM}_{10} \\
\mathrm{NO}_{2}\end{array}$ & $\begin{array}{c}1 / 3 / 2002-12 / 31 / 2008 \\
6 / 28 / 2001-12 / 31 / 2008\end{array}$ & $\begin{array}{l}24.18 \\
41.89\end{array}$ & $\begin{array}{l}11.25 \\
15.61\end{array}$ & $\begin{array}{l}7 \\
8\end{array}$ & $\begin{array}{l}144 \\
151\end{array}$ & $\begin{array}{l}2336 \\
2576\end{array}$ \\
\hline $\begin{array}{l}\text { Sydney } \\
\text { (Australia) }\end{array}$ & $\mathrm{PM}_{10}$ & $11 / 26 / 2003-12 / 21 / 2008$ & 19.35 & 7.29 & 5 & 54.4 & 1817 \\
\hline
\end{tabular}


Table 10

Summary Statistics - International Stock Returns

This table displays some summary statistics that describe the sample of international stock returns. Daily equity returns are expressed in percentage points.

\begin{tabular}{l|ccccccc}
\hline \multicolumn{1}{c}{ City } & Index & Sample Period & Mean & Std & Min & Max & Obs. \\
\hline $\begin{array}{l}\text { New York } \\
\text { (Unites States) }\end{array}$ & S\&P500 & $09 / 25 / 2001-12 / 31 / 2008$ & -.006 & 1.35 & -9.46 & 10.95 & 1831 \\
& NYSE Comp. & $09 / 25 / 2001-12 / 31 / 2008$ & .002 & 1.34 & -10.23 & 11.53 & 1831 \\
& Russell 1000 & $09 / 25 / 2001-12 / 31 / 2008$ & -.004 & 1.34 & -9.56 & 11.04 & 1831 \\
& Dow Jones Ind. & $09 / 25 / 2001-12 / 31 / 2008$ & .001 & 1.27 & -8.20 & 10.51 & 1831 \\
& S\&P600 Small Cap & $09 / 25 / 2001-12 / 31 / 2008$ & .019 & 1.49 & -11.62 & 8.12 & 1831 \\
$\begin{array}{l}\text { Madrid } \\
\text { (Spain) }\end{array}$ & IBEX 35 & $1 / 7 / 1987-12 / 31 / 2008$ & .026 & 1.35 & -9.59 & 10.12 & 5523 \\
Frankfurt & Datastream & $1 / 2 / 1990-12 / 31 / 2008$ & .025 & 1.22 & -8.49 & 9.13 & 4770 \\
$\begin{array}{l}\text { (Germany) } \\
\text { Shanghai }\end{array}$ & L-DAX & $11 / 4 / 2003-12 / 31 / 2008$ & .018 & 1.36 & -8.21 & 13.24 & 1303 \\
(China) & Datastream & $1 / 2 / 1998-12 / 31 / 2008$ & -.001 & 1.36 & -7.21 & 16.05 & 2797 \\
$\begin{array}{l}\text { Dublin } \\
\text { (Ireland) }\end{array}$ & SSE 50 & $1 / 2 / 2004-12 / 31 / 2008$ & .027 & 2.03 & -9.95 & 9.23 & 1214 \\
$\begin{array}{l}\text { Toronto } \\
\text { (Canada) }\end{array}$ & SSE 180 & $7 / 1 / 2002-12 / 31 / 2008$ & .013 & 1.86 & -9.75 & 8.95 & 1581 \\
$\begin{array}{l}\text { London } \\
\text { (UK) }\end{array}$ & DSE Overall & $1 / 1 / 1988-12 / 31 / 2007$ & .039 & 0.99 & -7.57 & 6.04 & 5021 \\
$\begin{array}{l}\text { Paris } \\
\text { (France) }\end{array}$ & DSX Comp. & $1 / 1 / 2003-12 / 31 / 2007$ & .059 & 0.74 & -3.58 & 2.37 & 1259 \\
$\begin{array}{l}\text { Sydney } \\
\text { (Australia) }\end{array}$ & Datastream & $1 / 1 / 2003-12 / 31 / 2007$ & .058 & 0.70 & -2.98 & 2.22 & 1304 \\
& FTSE 100 & $10 / 11 / 2001-12 / 31 / 2008$ & -.008 & 1.34 & -9.27 & 9.38 & 1826 \\
\hline & Datastream & $10 / 11 / 2001-12 / 31 / 2008$ & -.006 & 1.27 & -8.71 & 8.86 & 1826
\end{tabular}




\section{Table 11}

\section{International Evidence}

This table displays the results of estimating logit model [8] for each of the stock exchanges and market indices included in the sample. The dependent variable is the probability that equity returns will be positive on day $t$. The pollutant used as a proxy for air pollution is reported in the fourth column. The first column specifies the market for which the analysis is conducted. The second column indicates whether the corresponding stock exchange features a trading floor community. The third column lists the market indices employed in the analysis. The fifth column shows the marginal effect of a $10 \mu \mathrm{g} / \mathrm{m}^{3}$ increase in the air pollution proxy on day $t-1$ on the probability that stock returns will be positive on day $t$ (the coefficients on the remaining variables are not reported due to space limitations.). The sixth column reports the corresponding standard errors. The seventh column describes the period covered by the data, and the eighth column specifies the number of observations. The last column displays the pseudo $\mathrm{R}^{2}$ of the regression. One, two, and three asterisks denote statistical significance at the ten, five, and one percent level, respectively.

\begin{tabular}{|c|c|c|c|c|c|c|c|c|}
\hline $\begin{array}{c}\text { Stock } \\
\text { Market }\end{array}$ & $\begin{array}{l}\text { Trading } \\
\text { Floor }\end{array}$ & Index & Pollutant $_{t-1}$ & $\begin{array}{c}\text { Marginal } \\
\text { Effect }\left(10 \mu \mathrm{g} / \mathrm{m}^{3}\right)\end{array}$ & $\begin{array}{c}\text { Std } \\
\text { Error } \\
\end{array}$ & $\begin{array}{l}\text { Sample } \\
\text { Period } \\
\end{array}$ & Obs. & $\begin{array}{c}\text { Pseudo } \\
\mathbf{R}^{2} \\
\end{array}$ \\
\hline \multirow{5}{*}{$\begin{array}{l}\text { U.S. } \\
\text { (New York) }\end{array}$} & \multirow[t]{5}{*}{ Yes } & S\&P500 & $\mathrm{PM}_{2.5}$ & $-.0402 * *$ & .0165 & $\begin{array}{l}9 / 25 / 2001- \\
12 / 31 / 2008\end{array}$ & 1764 & .017 \\
\hline & & NYSE Comp. & $\mathrm{PM}_{2.5}$ & $-.0299 *$ & .0165 & $\begin{array}{l}9 / 25 / 2001- \\
12 / 31 / 2008\end{array}$ & 1764 & .010 \\
\hline & & Russell 1000 & $\mathrm{PM}_{2.5}$ & $-.0449 * * *$ & .0165 & $\begin{array}{l}9 / 25 / 2001- \\
12 / 31 / 2008\end{array}$ & 1764 & .015 \\
\hline & & Dow Jones & $\mathrm{PM}_{2.5}$ & $-.0393 * *$ & .0166 & $\begin{array}{l}9 / 25 / 2001- \\
12 / 31 / 2008\end{array}$ & 1764 & .016 \\
\hline & & $\begin{array}{l}\text { S\&P600 } \\
\text { Small Cap }\end{array}$ & $\mathrm{PM}_{2.5}$ & $-.0345 * *$ & .0164 & $\begin{array}{l}9 / 25 / 2001- \\
12 / 31 / 2008\end{array}$ & 1764 & .007 \\
\hline \multirow{4}{*}{$\begin{array}{l}\text { Spain } \\
\text { (Madrid) }\end{array}$} & \multirow[t]{4}{*}{ Yes } & IBEX 35 & $\mathrm{PM}_{10}$ & $-.0067 * *$ & .0034 & $\begin{array}{l}1 / 7 / 1987- \\
12 / 31 / 2008\end{array}$ & 5264 & .006 \\
\hline & & IBEX 35 & $\mathrm{NO}_{\mathrm{x}}$ & $-.0017 * *$ & .0008 & $\begin{array}{l}1 / 2 / 1990- \\
12 / 31 / 2008\end{array}$ & 4637 & .007 \\
\hline & & Datastream & $\mathrm{PM}_{10}$ & $-.0099 * *$ & .0040 & $\begin{array}{c}1 / 2 / 1990- \\
12 / 31 / 2008\end{array}$ & 4587 & .07 \\
\hline & & Datastream & $\mathrm{NO}_{\mathrm{x}}$ & $-.0020 * * *$ & .0008 & $\begin{array}{l}1 / 2 / 1990- \\
12 / 31 / 2008\end{array}$ & 4628 & .006 \\
\hline \multirow{4}{*}{$\begin{array}{l}\text { Germany } \\
\text { (Frankfurt) }\end{array}$} & \multirow[t]{4}{*}{ Yes } & L-DAX & $\mathrm{PM}_{10}$ & .0028 & .0094 & $\begin{array}{l}11 / 4 / 2004- \\
12 / 31 / 2008\end{array}$ & 1234 & .014 \\
\hline & & L-DAX & NO & $-.0086 * *$ & .0004 & $\begin{array}{l}11 / 4 / 2003- \\
12 / 31 / 2008\end{array}$ & 1237 & .016 \\
\hline & & Datastream & $\mathrm{PM}_{10}$ & -.0081 & .0065 & $\begin{array}{l}2 / 21 / 2001- \\
12 / 31 / 2008\end{array}$ & 1878 & .006 \\
\hline & & Datastream & NO & $-.0056^{* *}$ & .0023 & $\begin{array}{l}1 / 2 / 1998- \\
12 / 31 / 2008\end{array}$ & 2644 & .008 \\
\hline \multirow{4}{*}{$\begin{array}{l}\text { China } \\
\text { (Shanghai) }\end{array}$} & \multirow[t]{4}{*}{ Yes } & SSE 50 & $\mathrm{PM}_{10}$ & .0041 & .0005 & $\begin{array}{c}1 / 2 / 2004- \\
12 / 31 / 2008\end{array}$ & 1210 & .018 \\
\hline & & SSE 50 & $\mathrm{NO}_{2}$ & $-.0187^{*}$ & .0101 & $\begin{array}{l}1 / 2 / 2004- \\
12 / 31 / 2008\end{array}$ & 1210 & .019 \\
\hline & & SSE 180 & $\mathrm{PM}_{10}$ & .0021 & .0044 & $\begin{array}{l}7 / 1 / 2002- \\
12 / 31 / 2008\end{array}$ & 1574 & .017 \\
\hline & & SSE 180 & $\mathrm{NO}_{2}$ & $-.0141 *$ & .0082 & $\begin{array}{c}7 / 1 / 2002- \\
12 / 31 / 2008\end{array}$ & 1574 & .018 \\
\hline
\end{tabular}


Table 11 - Continued

\begin{tabular}{|c|c|c|c|c|c|c|c|c|}
\hline $\begin{array}{c}\text { Stock } \\
\text { market }\end{array}$ & $\begin{array}{l}\text { Trading } \\
\text { Floor }\end{array}$ & Index & Pollutant $_{\mathrm{t}-1}$ & $\begin{array}{c}\text { Marginal } \\
\text { Effect }\left(10 \mu \mathrm{g} / \mathbf{m}^{3}\right)\end{array}$ & $\begin{array}{l}\text { Std } \\
\text { Error }\end{array}$ & $\begin{array}{l}\text { Sample } \\
\text { Period }\end{array}$ & Obs. & $\begin{array}{c}\text { Pseudo } \\
\mathbf{R}^{2}\end{array}$ \\
\hline \multirow{4}{*}{$\begin{array}{l}\text { Ireland } \\
\text { (Dublin) }\end{array}$} & \multirow[t]{2}{*}{$\begin{array}{c}\text { Yes till } \\
\text { June 6, } 2000\end{array}$} & ISEQ Overall & $\mathrm{NO}_{2}$ & $-.0048 * *$ & .0022 & $\begin{array}{l}1 / 4 / 1988 \\
6 / 6 / 2000\end{array}$ & 2307 & .030 \\
\hline & & Datastream & $\mathrm{NO}_{2}$ & $-.0036^{*}$ & .0021 & $\begin{array}{l}1 / 4 / 1988- \\
6 / 6 / 2000\end{array}$ & 2308 & .029 \\
\hline & \multirow{2}{*}{ No thereafter } & ISEQ Overall & $\mathrm{NO}_{2}$ & -.0073 & .0102 & $\begin{array}{c}6 / 7 / 2000- \\
12 / 31 / 2007\end{array}$ & 1781 & .009 \\
\hline & & Datastream & $\mathrm{NO}_{2}$ & -.0109 & .0103 & $\begin{array}{c}6 / 7 / 2000- \\
12 / 31 / 2007\end{array}$ & 1782 & .010 \\
\hline \multirow{2}{*}{$\begin{array}{l}\text { Canada } \\
\text { (Toronto) }\end{array}$} & \multirow[t]{2}{*}{ No } & TSX Comp. & $\mathrm{PM}_{2.5}$ & .0183 & .0231 & $\begin{array}{c}1 / 2 / 2003- \\
12 / 31 / 2007\end{array}$ & 1257 & .008 \\
\hline & & Datastream & $\mathrm{PM}_{2.5}$ & .0213 & .0229 & $\begin{array}{c}1 / 2 / 2003- \\
12 / 31 / 2007\end{array}$ & 1302 & .007 \\
\hline \multirow{4}{*}{$\begin{array}{l}\text { UK } \\
\text { (London) }\end{array}$} & \multirow[t]{4}{*}{ No } & FTSE 100 & $\mathrm{PM}_{10}$ & -.0166 & .0141 & $\begin{array}{c}\text { 6/3/2003- } \\
12 / 31 / 2008\end{array}$ & 906 & .028 \\
\hline & & FTSE 100 & $\mathrm{NO}_{\mathrm{x}}$ & -.0007 & .0027 & $\begin{array}{l}10 / 11 / 2001- \\
12 / 31 / 2008\end{array}$ & 1656 & .011 \\
\hline & & Datastream & $\mathrm{PM}_{10}$ & -.0203 & .0139 & $\begin{array}{c}\text { 6/3/2003- } \\
12 / 31 / 2008\end{array}$ & 906 & .026 \\
\hline & & Datastream & $\mathrm{NO}_{\mathrm{x}}$ & -.0003 & .0027 & $\begin{array}{l}10 / 11 / 2001- \\
12 / 31 / 2008\end{array}$ & 1656 & .009 \\
\hline \multirow{4}{*}{$\begin{array}{l}\text { France } \\
\text { (Paris) }\end{array}$} & \multirow[t]{4}{*}{ No } & CAC 40 & $\mathrm{PM}_{10}$ & .0124 & .0118 & $\begin{array}{c}1 / 3 / 2002- \\
12 / 31 / 2008\end{array}$ & 1627 & .008 \\
\hline & & CAC 40 & $\mathrm{NO}_{2}$ & .0008 & .0094 & $\begin{array}{l}6 / 28 / 2001- \\
12 / 31 / 2008\end{array}$ & 1797 & .008 \\
\hline & & Datastream & $\mathrm{PM}_{10}$ & .0068 & .0117 & $\begin{array}{c}1 / 3 / 2002- \\
12 / 31 / 2008\end{array}$ & 1627 & .004 \\
\hline & & Datastream & $\mathrm{NO}_{2}$ & -.0003 & .0093 & $\begin{array}{l}6 / 28 / 2001- \\
12 / 31 / 2008\end{array}$ & 1797 & .002 \\
\hline \multirow{2}{*}{$\begin{array}{l}\text { Australia } \\
\text { (Sydney) }\end{array}$} & \multirow[t]{2}{*}{ No } & $\begin{array}{l}\text { ASX All } \\
\text { Ordinaries }\end{array}$ & $\mathrm{PM}_{10}$ & .0158 & .0217 & $\begin{array}{l}11 / 26 / 2003- \\
12 / 31 / 2008\end{array}$ & 1268 & .012 \\
\hline & & Datastream & $\mathrm{PM}_{10}$ & .0135 & .0217 & $\begin{array}{l}11 / 26 / 2003- \\
12 / 31 / 2008\end{array}$ & 1268 & .012 \\
\hline
\end{tabular}

